\title{
Irrigation in the Khorezm oasis, past and present: a political ecology perspective
}

\author{
Elizabeth Baker Brite ${ }^{1}$ \\ Purdue University, USA
}

\begin{abstract}
The Khorezm oasis sits at the epicenter of an environmental disaster. Since the late $19^{\text {th }}$ century, the continual expansion of irrigation in this region has altered the natural hydrology of the Amu Darya delta, leading to widespread desertification and the near total disappearance of the world's fourth largest lake, the Aral Sea. The situation is widely acknowledged as an environmental catastrophe of unprecedented scale, and yet it is not the first irrigation crisis in Khorezmian history. Numerous events of irrigation collapse are recorded in the archaeological record of this oasis, with many in the scientific community now very interested in this past record for its potential to inform on the modern crisis. Unfortunately, there has also been a tendency to overlook the different historical conditions that led to irrigation in this oasis over the last three millennia. In this article, I take an alternative approach that draws on political ecology's insights about the cultural embeddedness of environmental behavior. I compare two periods of irrigation in Khorezm, one ancient and the other modern, to show how the particular social contexts of each period shaped irrigation schemes in different ways. Significantly different design and implementation features are apparent in the ancient versus modern systems, with vastly different implications for environmental sustainability and human well-being.
\end{abstract}

Keywords: water, irrigation, Aral Sea, archaeology, collapse, Soviet Union, nomadic pastoralism

\section{Résumé}

L'oasis de Khorezm se trouve à l'épicentre d'une catastrophe écologique. Depuis la fin du 19e siècle, l'expansion continue de l'irrigation dans cette région a modifié l'hydrologie naturelle du delta Amou-Daria. Cela a conduit à la désertification généralisée, et la disparition quasi totale de quatrième plus grand lac du monde, la mer d'Aral. La situation est largement reconnu comme une catastrophe environnementale à une échelle sans précédent, et pourtant il est pas la première crise de l'irrigation dans l'histoire du Khorezm. L'effondrement de l'irrigation a été enregistrée plusieurs fois dans le dans le dossier archéologique. Certains scientifiques pensent que le passé peut aider à comprendre la crise actuelle. Malheureusement, il ya également eu une tendance à négliger les différentes conditions historiques qui ont conduit à l'irrigation dans cette oasis, ce qui rend les comparaisons difficiles. Dans cet article, je prends une approche alternative qui attire sur les idées de l'écologie politique sur l'implantation culturelle du comportement environnemental. Je compare deux périodes de l'irrigation dans Khorezm, un ancien et l'autre moderne, pour montrer comment les contextes sociaux particuliers à chaque période ont contribué à créer les différents systèmes d'irrigation. Conception et réalisation étaient très différents, conduisant à des résultats différents pour la durabilité environnementale et le bien-être humain.

Mots clés: l'eau, l'irrigation, la mer d'Aral, l'archéologie, l'effondrement, l'Union soviétique, le pastoralisme nomade

\section{Resumen}

El oasis de Khorezm es el epicentro de un desastre ambiental. Desde el final del siglo 19, la expansión desenfrenada de la irrigación en esa región ha alterado la hidrología natural de la delta del Río Amu Darya, conduciendo a la desertificación y la casi total desaparición del cuarto lago más grande del mundo, el Mar

\footnotetext{
${ }^{1}$ Dr. Elizabeth Brite, Clinical Assistant Professor, Honors College, Purdue University, 205 N. Russell Street, West Lafayette, IN 47906-4238, USA. Email: britee "at" purdue.edu. The author wishes to thank the JPE editors, Simon Batterbury and Casey Walsh, and the two anonymous reviewers for their guidance. Portions of this article were included in an earlier draft, and I am grateful to Monica Smith and Nancy Levine for their comments. I would not have been able to write this article without the ongoing support of the Purdue University Honors College. Finally, Gulshad Botirova and her family, Yermak, Alisher, and Mansur, provided me cherished glimpses into their daily lives that inspired this work; this paper is dedicated to her memory.
} 
Aral. Aunque la situación es ampliamente reconocida como un desastre ambiental de una escala sin precedente, no es la primera vez en la historia de Khorezm que la irrigación está en crisis. La evidencia arqueológica nos cuenta de varios colapsos en este oasis, de suma interés para la comunidad científica por su potencial de iluminar a la crisis actual. Desafortunadamente hay una tendencia de ignorar las condiciones históricas particulares que dieron base al riego en distintos momentos de los últimos tres milenios. En este artículo parto de la idea que el comportamiento ecológico es fundamentalmente cultural; idea central de la ecología política. Hago una comparación entre dos periodos del riego en Khorezm, uno antiguo y el otro moderno, para mostrar la manera en que los contextos sociales de cada periodo dieron forma a los respectivos sistemas de riego. Los dos periodos están marcados por diseños y implementaciones de sistemas de riego muy distintos, con implicaciones igualmente distintos para la sustentabilidad del ambiente y el bienestar humano.

Palabras clave: agua, el riego, el Mar de Aral, la arqueología, el colapso, la Unión Soviética, el pastoreo nómada

\section{Резюме}

Хорезмский оазис находится в эпицентре экологической катастрофы. С конца 19-го века постоянное развитие ирригационных систем в этом регионе изменило естественную гидрологию дельты Амударьи, что привело к широкомасштабному опустыниванию и почти полному исчезновению четвертого по величине озера в мире - Аральского моря. Ситуация широко признается экологической катастрофой невиданного масштаба, и все же это не первый кризис орошения в истории Хорезма. Многочисленные события ирригационного распада записаны в археологической летописи этого оазиса, многие в научном сообществе в настоящее время очень заинтересованы в прошлых записях для лучшего понимания современного кризиса. К сожалению, это привело к тенденции игнорирования различных исторических условий, которые привели к орошению в Хорезмском оазисе на протяжении последних трех тысячелетий. В этой статье применяется альтернативный подход, который опирается на идеи политической экологии культурного аспекта поведения в окружающей среде. Я сравниваю два периода орошения в Хорезмском оазисе, один древний и один современный, чтобы показать, как специфический социальный контекст каждого периода изменил форму ирригационных систем различными способами. Значительно отличающиеся функции по разработке и внедрению очевидны в древней и современной системах, с совершенно разными последствиями для устойчивости окружающей среды и человеческого благополучия.

Ключевые слова: вода, орошение, Аральское море, археология, коллапс, Советская, кочевое скотоводство

\section{Introduction}

..the water that serveth all the country is drawn by ditches out of the river Oxus unto the great destruction of the said river, for which it falleth not into the Caspian Sea as it hath done in times past, and in short time all that land is like to be destroyed, and to become a wilderness for want of water, when the river Oxus shall fail.

Anthony Jenkinson, 1558 (Morgan and Coote 1885:70)

Asia's arid interior is home to several well-watered zones, known as the desert oases, where humans have practiced artificial irrigation for the last seven thousand years (Figure 1). In 1558, a British merchant named Anthony Jenkinson travelled through one of these regions, the Khorezm oasis in the delta of the Amu Darya River (in antiquity, the 'River Oxus'). He described a perplexing feature of local life. Though irrigation was a ubiquitous strategy among Khorezm's inhabitants, Jenkinson noted how the canals seemed to place obvious, unsustainable stresses on the river ecosystem. He predicted that these pressures would lead to failure, and indeed, it was only fifteen years later when the entire irrigation network did collapse due to overdiversion of the river's waters (Boomer et al. 2000:1266; Morgan and Coote 1886:71). Numerous other archaeological, ethnohistoric, and ethnographic sources tell similar tales, suggesting that irrigation collapses have been recurrent events in the Khorezm oasis for millennia, in the time prior to and following Jenkinson's 
travels (al-Biruni 1879:41; Andrianov 1969; Boroffka 2010; Cretaux et al. 2013; Le Strange 1930:447; Olufsen 1911: 238-9, 262).

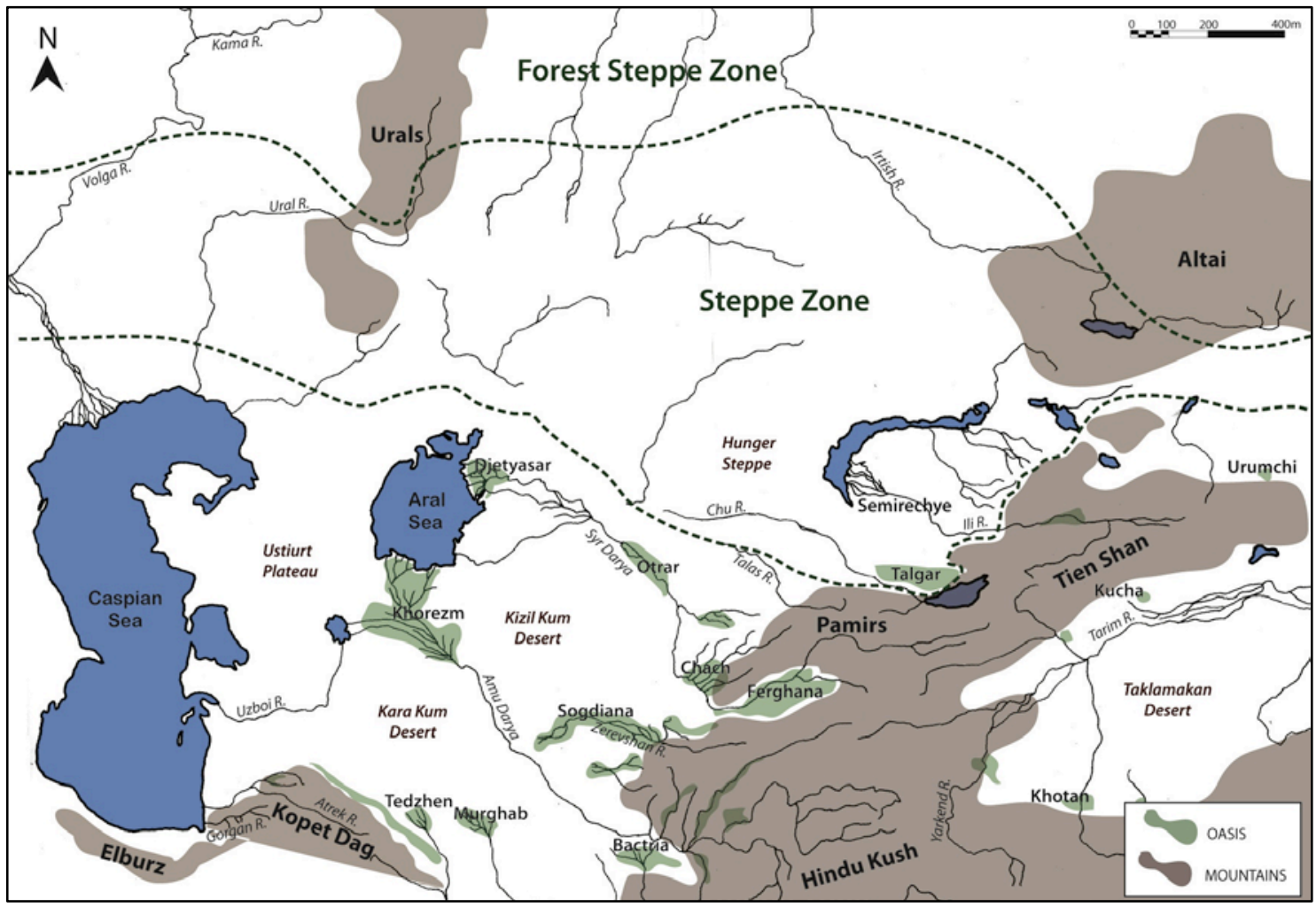

Figure 1: Inner Eurasia's desert oases.

The Khorezmian collapses appear to result from a poor fit between irrigation strategies and the desert oasis environment, and they raise an essential question about the history of human decision-making in this region. Why has irrigation been used so extensively there for thousands of years, even though it is prone to collapse? In this article, I attempt to address this question using insights from political ecology. Specifically, I explore how irrigation may be better understood as a practice embedded within a broader cultural system (Greenberg and Park 1994). I utilize political ecologists' concept of contextualization to illustrate how irrigation practices are influenced by a wide array of social interactions, which shape environmental conditions and affect human perceptions of the environment, and responses to it (Penna-Firme 2013; Vayda 1983; Vayda and Walters 1999; Walters and Vayda 2009).

Discerning the different social factors that influence irrigation decisions in the Khorezm oasis is important because this region sits today at the epicenter of an environmental disaster. The overuse of irrigation in Khorezm has caused widespread desertification, changes so severe that they have led to the near total disappearance of the world's fourth largest lake, the Aral Sea (Glantz 1999; Micklin 1988, 1992, 2007, 2010). The disaster has attracted international attention for the extremely negative impacts it is having on the region's climate, on human health, and on the long-term sustainability of the oasis ecosystem (UNDP-Uz 2011; UNEP 2005). The long history of irrigation in Khorezm in pre-modern times assists understanding and addressing current problems, but scientists have until now paid too little attention to the importance of cultural context in shaping irrigation systems. This has engendered a misunderstanding of the diversity of practices that have led to irrigation of the Khorezm oasis over the last several thousand years, and thus an oversimplified view of the form, causes, and consequences of human-induced environmental change. 
The Khorezm oasis has a well-documented archaeological record of repeated phases of irrigation expansion and collapse (Andrianov 1969, 1995; Gul'yamov 1957; Lewis 1966; Tolstov 1948, 1962; Tolstov and Kes 1960). Over the last two decades, scientists have become increasingly aware that the Aral Sea has also had significant changes in water volume during this same time, and they have made numerous attempts to align the archaeological and environmental data sets to determine whether irrigation caused Aral Sea recessions in the ancient past in ways similar to today (Boomer et al. 2000, 2009; Boroffka 2010; Boroffka et al. 2005, 2006; Cretaux et al. 2013; Letolle et al. 2007; Maev et al. 1991; Oberhansli et al. 2007; Reinhardt et al. 2008; Sorrel et al. 2006, 2007). A problem arises, however, because these studies assume that the same human causes underlie historically separate events of environmental change; that is, they assume that Khorezm's irrigation systems have always been designed to maximize the use of water resources for intensive agriculture at the expense of the natural environment. The difficulty with these assumptions, as this article attempts to show, is that the cultural contexts of irrigation development were different throughout history. As a result, people's attitudes, behaviors, and their actions towards the environment were not the same in any given period, and thus their irrigation systems, and their consequences, took different forms.

To illustrate this point, this article compares two different phases of irrigation in the Khorezm oasis, using evidence gathered from the archaeological, historical, and ethnographic records. The modern period, from the late $19^{\text {th }}$ century to the present, is compared to the first major apex of irrigation in the 7th century B.C. - 4th century A.D. In both phases, periods of intensive irrigation development were followed by widespread deterioration. This is where the similarities end, however, as each of these phases show remarkably different social conditions under which irrigation practices rose and fell.

In modern times, irrigation of the Khorezm oasis has been a planned effort orchestrated by centralized managerial authorities, aimed at expanding intensive, sedentary agriculture to its maximum possible extent (O'Hara 2000; O'Hara and Hannan 1999; White 2013). This system emerged first in the context of colonization, and later as part of the Soviet command economy, and took an explicitly agrarian approach to land use focused on the production of a limited range of economically valuable but water-intensive crops, especially cotton. Investments in massive irrigation channels such as the Kara Kum canal, one of the longest irrigation canals in the world, were envisioned as permanent alterations to the landscape that could support the unfettered development of cities and open new agricultural lands in previously marginal desert zones. Nearly two centuries of social and environmental augmentation have intimately tied the livelihoods of governments and people in the former Central Asian republics to this production system, making it especially hard for them to adapt as irrigation agriculture has expanded beyond the carrying capacity of the oasis (White 2013). Collapse has thus been experienced not only as shortsighted, deleterious environmental change, but also as an inability among local people and state institutions to respond through the wide-scale social, agricultural, and infrastructural changes needed for adaptation.

Archaeological data suggest remarkably different social conditions in the ancient period. In contrast to modern times, the Khorezm oasis in the 7th century B.C. - 4th century A.D. shows little evidence of strong, centralized state control (Betts 2006; Kidd and Betts 2010: 682-4). Opportunities to plan and execute largescale, centrally managed irrigation networks were thus limited, and complex canal systems may have arisen instead either through consensus, by the linking of many smaller, community-based networks over time (Stride et al. 2009; Tsvetsinskaya et al. 2002: 269-270), or through competitive canal building among local elites (Lamberg-Karlovsky 1994). The social landscape of water users was also different. Diverse communities existed along Khorezm's ancient canals, whose inhabitants integrated steppe nomadic and sedentary agrarian ways of life (Negus Cleary 2008, 2013, 2015). These ancient populations produced art and engaged in rituals that synthesized the ideologies of the oasis and the steppe (Betts et al. forthcoming; Kidd and Betts 2010; Kidd 2011, 2012; Kidd et al. 2008; Yagodin et al. 2009), and they mixed agricultural and pastoral production as a key adaptive response to Khorezm's volatile resource environment (Brite 2011, 2014; Brite and Marston 2013). As a result, they designed their irrigation systems to meet the diverse needs of people practicing semi-nomadic pastoralism as well as agriculture. There was also variation among the different sub-regions of the oasis in terms of balances between agriculture and pastoralism, and in the ways nomads and sedentists interacted, which impacted the design of their irrigation systems (Andrianov 1969; Tsvetsinskaya et al. 2002). For ancient inhabitants living in these highly diversified and decentralized 
contexts, the irrigation collapse they endured may have been as much a process of making adjustments to an already dynamic agropastoral way of life, as it was an act of scaling back or abandoning their irrigation canals.

By drawing attention to these differences between past and present systems in the Khorezm oasis, this study seeks to situate itself within a larger body of literature in political ecology that emphasizes the importance of social context in understanding environmental change. This literature aims to provide a more nuanced, detailed picture of the factors that influence human environmental behaviors, in the hopes that this information can be used to address destructive practices (Vayda 1983:275-277). In the case of the Khorezm oasis, insights into the contextual differences between past and present irrigation can help to unravel a common paradigm, which assumes that resource depletion is a timeless human practice, and that irrigation canals are an inevitable result of the tensions between humans and nature. To the contrary, the following analysis will attempt to show how irrigation in the Khorezm oasis is and has always been a consequence, and not a cause, of particular modes of cultural production. As White (2013) has observed, it is an environmental behavior driven by the economic, political, and ideological contexts of its time. It is argued here that closer examination of these realities leaves open the possibility that there can be many different ways to live in the Aral Sea Basin, with vastly different possible outcomes for human and environmental well-being.

\section{The importance of social context}

When people make changes to their environment, their actions do not occur in a vacuum. People make environmental decisions based on a variety of information, including observations of the natural world, but also a large amount of social information. Factors such as access to markets, competition for resources, and beliefs about nature all impact what people do environmentally, when, and how they do it. As a result, when humans interact with an ecosystem they shape their material world to address not only the natural, but also the social realm of human experience, producing systems that speak to each simultaneously. Understanding the social contexts that motivate and shape human environmental behavior is therefore critical to the study of human-environment relations, including events of human-induced environmental change.

The human ecologist Andrew Vayda was among the first to bring attention to the importance of social context to studies of environmental change. In his work on deforestation in Indonesia (1983), Vayda observed that people's individual decisions to cut down trees, move to a city, or irrigate farmland were based on their social experiences of the world around them. The large-scale patterns of change that ecologists observe such as regional deforestation, Vayda argued, emerged because people shared similar experiences and came to similar conclusions about how to act in the environments in which they live. His work has inspired a whole body of studies in human ecology focused on revealing the social factors that motivate human environmental behavior, in order to understand global scale change (Vayda 1983, 1990, 1994; Vayda and McCay 1975, 1977; Vayda and Walters 1999; Walters et al. 2008; Walters and Vayda 2009).

Anthropologists and political ecologists since Vayda have worked to develop methodologies to deconstruct people's environmental decision-making, drawing connections between human actions and the different scales at which change occurs (McCay 2008; Penna-Firme 2013). They have advanced research that gives primacy to the social context, and not just the natural conditions or global forces, which shape human environmental behavior. Several context-based approaches have been developed, including "progressive contextualization" and "event ecology", and these share certain essential elements:

(1) a pragmatic research question focused on explaining a particular human behavior that contributes to environmental change, in terms of lived experience;

(2) investigation of individuals' actions at the ground level, and;

(3) an accounting of the factors of culture, governance, nature, and power that influence and affect individual decisions. 
A context-based research approach can provide a new perspective on the phenomenon of irrigation in the Khorezm oasis. First, it opens up new possibilities for investigative research because it does not assume that environmental change is the same over time. Separate historical events of irrigation emergence and decline that appear in the same environmental setting, and which may even appear materially similar at global scales, can in fact differ significantly in terms of lived human experiences at the ground level. Second, a context-based approach requires investigation of people's individual actions, and thereby avoids essentialized notions of human behavior. This is a particularly useful approach to the Khorezm oasis, where designations like "irrigation farmer" or "nomadic pastoralist" often fail to describe the full range of people's environmental activities (Kidd and Betts 2010; Negus Cleary 2015; Sala 2003). Existing models of oasis irrigation have yet to adequately account for these complex agropastoral practices (Stride et al. 2009). Finally, a context-based approach can help to reveal how changing cultural forces have shaped Khorezmian oasis irrigation differently through time, by tasking the observer with defining the shared human customs, beliefs, political relationships, and economic factors that drive ecological change.

\section{Irrigation in the desert oases of Inner Eurasia}

Khorezm is one of the largest of several desert oases in Inner Eurasia. This region is comprised predominantly of desert and steppe and is cut by two major rivers, the Amu Darya and Syr Darya, and by a few other minor rivers, including the Zerevshan, the Murghab, and the Tedzhen. The rivers create riparian environments ('oases') that are otherwise isolated within a vast desert belt that stretches across southern Inner Eurasia, from the eastern shores of the Caspian Sea to Mongolia.

Access to water and opportunities for cultivation have made Inner Eurasia's desert oases focal points for human settlement since the Neolithic (Harris 2010). Irrigation agriculture first appeared in the oases of southern Turkmenistan in the Chalcolithic or Bronze Age (Lewis 1966; Miller 1999), but it was not until the early Iron Age (ca. early $1^{\text {st }}$ Millennium B.C.) when complex irrigation works began to appear more broadly. Major irrigated oases of this latter period included the Khorezm oasis, as well as the oases of Bactria, Sogdiana, Ustrushana, Chach, Otrar, and Ferghana. Several important eastern oases also existed in the region of the Tarim Basin. In the Islamic periods, all of the major Silk Road trading cities, including Khiva, Samarkand, Bukhara, and Kashgar, could be found in these agricultural hubs. Today, the Inner Eurasian desert oases are the main regions of agricultural production for the Central Asian republics, supporting a significant portion of these countries' agricultural sectors, especially in Turkmenistan and Uzbekistan.

\section{Climate and environment}

Despite an arid climate and low annual precipitation, Inner Eurasia's desert oases can be exceptionally good for places for agriculture (Gintzburger et al. 2003:35-40). Their loess and sierozem (gray desert) soils are fertile under irrigation, and in their natural state oases spring up along narrow plains that follow a river's path. This creates lush tracts of shrubland that stand in dramatic contrast to the surrounding desert (Figures 2 and 3). With artificial irrigation, humans can further enhance these properties, extending the arable land far beyond its natural boundaries by encroaching upon the dry rangelands of the desert.

Maintaining this fertility over the long-term is difficult, however, because the water and soils of the desert oases are highly susceptible to change. The region's major rivers originate from some of the highest mountain ranges in the world, producing large sediment loads that drain down into the topographically flat, rainless Aral Sea Basin. Large sediment deposits on this flat terrain cause the rivers and their tributaries to continually change course. The oases' shallow desert soils are also easily eroded by human activities, and they are prone to waterlogging and secondary salinization when irrigated. The product of these effects is that the locations of water and fertile land are constantly shifting in Inner Eurasian oases, placing a limit on the length of time a plot of land can be productively irrigated (Tsvetsinskaya et al. 2002). It also means that the boundaries between an oasis and its surrounding desert rangelands are in constant flux. This capriciousness invariably leads people to pursue different strategies to mitigate landscape change, strategies that may draw inhabitants into closer relations with their rangeland neighbors, or place them at odds with them. 


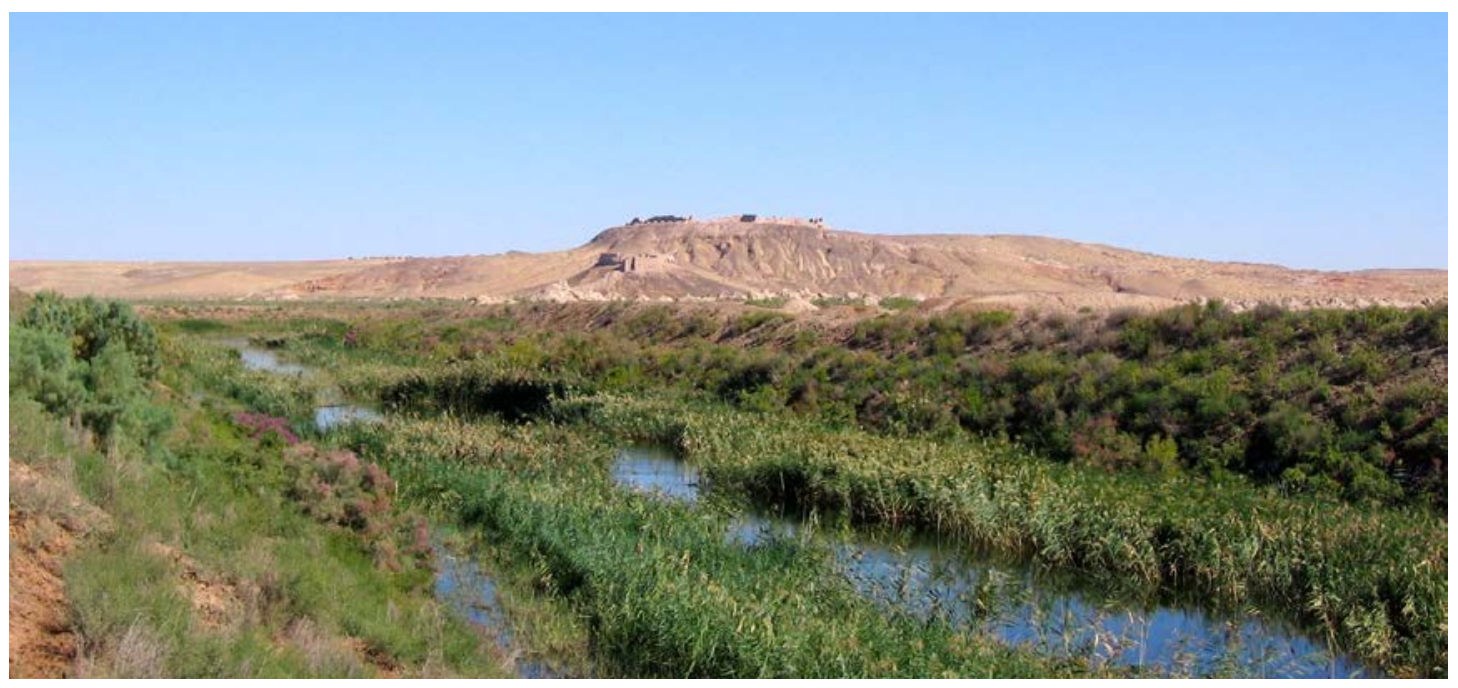

Figure 2: Irrigation canal and adjacent desert in the Khorezm oasis, Uzbekistan. Note how the dense vegetation along the canal directly abuts the desert expanse. The site of Ayaz kala ( $4^{\text {th }}$ century B.C. $-7^{\text {th }}$ century A.D.) can be seen on the hilltops in the background.

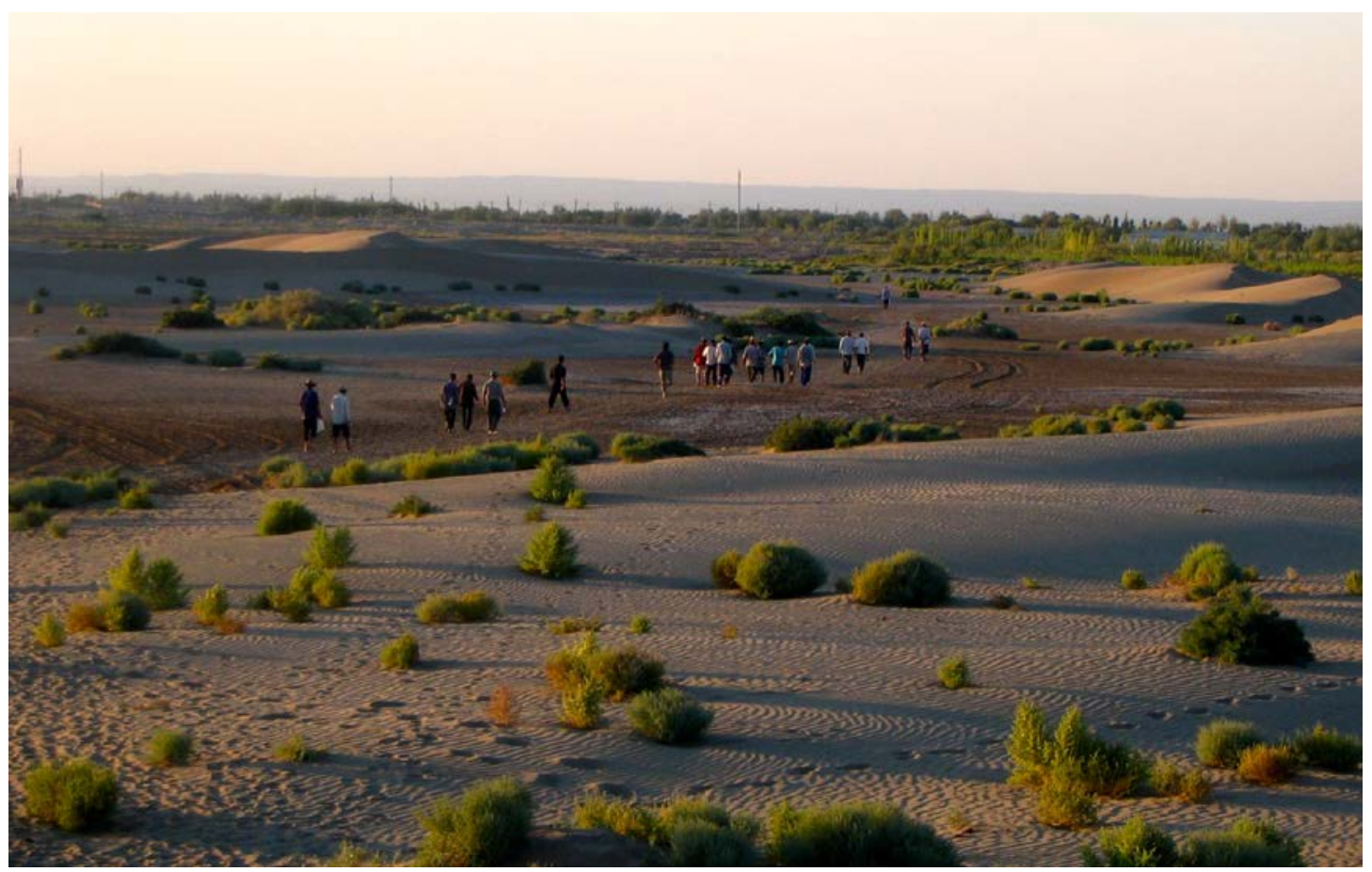

Figure 3: Workmen returning to Kolkhoz Azat from the archaeological site of Akchakhan kala, Khorezm oasis, Uzbekistan. The agricultural zone can be seen along the horizon. In the foreground, the barkhan sand dunes, takyr salt flats, and saxsual bushes of the surrounding desert are visible. 


\section{Irrigation in ancient times}

In ancient times, integration with the desert rangelands was a key component of irrigation strategies in Inner Eurasia's desert oases. Specific practices were usually reconciled to an oasis's particular river system. For example, in piedmont oases such as those in the Kopet Dag foothills and in the Ferghana valley, where mountain streams provide small but stable flows, inhabitants cultivated lower yielding, drought tolerant crops, such as millet, barley, wheat, and green gram (mung bean), that could be readily combined with the herding of sheep and goats (Gorbunova 1986; Harris 2010:233; Sala 2003; Miller 1999; Moore et al. 1994; Sarianidi 1992). These agropastoral activities were supported with still-water irrigation systems that used gravity flow, basin, and basin catchment techniques (Lewis 1966:477-478; Sala 2003:6-7; Scarborough 2003:99-102). This kind of agropastoralism was in place in the Kopet Dag foothills as early as the $5^{\text {th }}$ Millennium B.C. (Harris 2010:69; Sala 2003), and existed from Neolithic times through the $1^{\text {st }}$ Millennium A.D. in the Ferghana valley (Gorbunova 1986, 1992; Saidov et al. 2011).

In other arable oases in Inner Eurasia, rangeland production accompanied the development of largescale, moving-water irrigation systems, which were required to manage the flow of larger rivers. These kinds of systems were established beginning in the $1^{\text {st }}$ Millennium B.C. in the lowland river oases of the Murghab (Merv oasis), in Dahistan (the Gorgan plain), along the Surkhan Darya, the Balkh-ab, and Kashka Darya (Bactrian oasis), along the Zerevshan River (Bukharan and Sogdian oases), in the Amu Darya delta (Khorezm oasis) and Syr Darya deltas, and along the middle Syr Darya (Chardara and Otrar oases)(Sala 2003:5; Lewis 1966:479). The scope of ancient irrigation activities varied among these oases, with the Amu Darya delta probably receiving the most extensive development in antiquity (Mukhamedjanov 1994:259).

Despite having abundant water and large-scale irrigation systems, these lowland oases were still unstable, and the response was to combine agriculture with pastoralism. Along the Syr Darya, mountain rainfall patterns cause dramatic annual fluctuations in river levels that affect subsistence. Clark et al. (2005) showed how these fluctuations impacted yearly agricultural yields in the Otrar oasis in the $1^{\text {st }}$ and $2^{\text {nd }}$ Millennia A.D., which Sala (2003:10-13,17-18) suggests were dealt with by expanding or contracting cultivation in accordance with water availability, and relying on pastoral production to compensate for shortfalls. Expanding/contracting agropastoralism was also the prevailing practice throughout the whole $1^{\text {st }}$ Millennium B.C. and $1^{\text {st }}$ Millennium A.D. in the delta of the Syr Darya, where semi-mobile inhabitants grazed flocks along river corridors in the land between tributaries, but also practiced opportunistic shifting agriculture. This system relied on a complex, seasonal reservoir irrigation network to catch and distribute flood waters to a suite of potential agricultural fields, which were selectively cultivated or left fallow depending on that year's seasonal flood pattern (Andrianov 1969; Levina 1996; Sala 2003:11; Tolstov 1962; Zonn 2009:96).

Other lowland oases had perennial, flowing irrigation systems in ancient times that supported more intensive cultivation, but these were still usually integrated in some way with the rangelands. In the northern Bactrian oasis (the Upper Surkhan Darya plain), for example, irrigation agriculturalists lived in small communities in close proximity to pastoralists and maintained shared regional centers where they could regularly exchange goods (Stride 2007:106, 110-112). In Sogdiana in the $1^{\text {st }}$ Millennium B.C. $-1^{\text {st }}$ Millennium A.D., irrigation systems were linked together across the rangelands to form one large system, the Dargom canal (Stride et al. 2009). Considering the production landscapes that were crisscrossed by the Dargom, Stride et al. (2009) surmised that it must have been achieved through consensus and alliances with neighboring pastoralist groups, and thus was a principal mechanism through which agricultural and pastoral communities became tied together. As one of the largest and longest lasting ancient irrigation systems in Inner Eurasia, the Dargom provides a crucial example of the possibilities for the co-evolution of agriculturalists and pastoralists into a shared, regional irrigation society in the $1^{\text {st }}$ Millennium B.C. $-1^{\text {st }}$ Millennium A.D.

\section{Irrigation since the 19th century}

The social dynamics of the $19^{\text {th }}$ century transformed Inner Eurasia's desert oases into highly productive agricultural regions. Colonial and later, Soviet land development policies sowed vast portions of these lands 
to a limited number of globally valuable crops, especially cotton, which were supported through the construction of massive, highly integrated irrigation networks. At the same time, social engineering projects collectivized farmland and sedentarized nomadic groups, all but obliterating older forms of mixed agropastoral production based on nomadic and semi-nomadic ways of life.

The modern era of production in the Inner Eurasian desert oases has concentrated on enhancing and extending intensive agriculture and de-emphasizing nomadic rangeland animal husbandry. Beginning in the middle 19th century, Russian imperial interests turned to the Inner Eurasian desert oases in the pursuit of new opportunities for commodity production. Cotton farming within Russian territory was especially desired due to import shortages from the American Civil War. In response, upon annexation of "Russian Turkestan" (parts of modern day Kazakhstan and Uzbekistan), teams of Russian agricultural and engineering experts were sent to the region to assess its potential for large-scale cotton production (O'Hara 2000:369). A number of ambitious projects were conceived, with the intention of constructing new agricultural systems in irrigated oases and expanding irrigation further out into the desert (O'Hara 2000:369; O'Hara and Hannan 1999:25; Micklin 2014:209).

In the colonial period, the aim of "civilizing" the peoples of the East was tied to imperial desires for cotton and for a water route to India, in order to garner support for entrepreneurial enterprises aimed at irrigating Inner Eurasian oases. Colonial interventions in oasis irrigation and local water politics were significant, but largely unsuccessful. An attempt to irrigate the Golodnaya Steppe met with major waterlogging and salinization problems, and the loss of over $60 \%$ of the newly irrigated land within 15 years of development (Micklin 2014:210). In the Khanate of Khiva, Russian colonists tried and failed to direct local authorities to build new canals in ways that would restructure the physical and cultural landscape in their favor (Shioya 2014). As Pravilova (2009) points out, these were largely utopian endeavors pursued by private activists within the imperial administration, which failed because they were not matched with sufficient governmental support.

The Bolshevik Revolution and the transition to Soviet rule brought on a new, much more accomplished phase of transformation in the Inner Eurasian oases, in which the ideological, political, and economic goals of the state were realized through irrigation development. Massive central investments in irrigation agriculture were seen as a way to showcase the Soviet regime as a civilizer of 'backwards' societies, moving the peoples of Inner Eurasia along towards more evolved forms of socialism, while at the same time creating new, more modern systems of economic production (Teichmann 2007:503). Lenin himself issued the edict in 1920 calling for the "reconstruction" of cotton industry in the Central Asian republics, and remarked at the centrality of irrigation development to larger political aims, "...irrigation...changes the country; it leads to rebirth, buries the past and enforces the transition to socialism" (O'Hara and Hannen 1999:25; Teichmann 2007:503). Right from the beginning, large sums of government money were allocated for these new irrigation plans, which focused on the construction of huge, highly integrated systems based on Tsarist-era designs (O'Hara 2000:370). Irrigation canal expansion sat at the core of Soviet political, ideological, and economic objectives in the Central Asian republics from the 1920s onward.

The Bolshevik view asserted that the traditional system of agriculture needed to be completely torn down before it could be replaced with a new, more modern, centrally-managed, industrialized system. In 1925, all lands in the Central Asian republics were nationalized for redistribution into large, collective farms, or kolkhoz and sovkhoz. Along with the confiscations of property and deprivations of the peasantry that ensued, traditional, small agricultural plots, which had previously been watered by village-level irrigation systems and sustained with techniques such as perennial tree cultivation, were converted into large, unobstructed fields (Micklin 2014). The new system was designed to accommodate heavy farming machinery and the production of a limited number of high-value crops, especially cotton, which by 1933 had grown to over 50\% of the region's sown area (Micklin 2014:214 and table 8.1). Renovation and expansion of the irrigation systems were an integral part of the new design.

Efforts to build truly massive canals began in 1938, and were meant not only to transform agriculture, but also to convert the spirit of the people. Five thousand young men from Turtkul in Karakalpakstan were "organized" (i.e., forced) to dig the Kyrkyz canal in 1941, in an attempt to create 20,000 hectares of new 
agricultural land. Only 1000 hectares were achieved. The Great Ferghana Canal was built in the autumn/winter of 1939-40 by half a million laborers taken from all over Uzbekistan. The act of digging these canals was as important as the infrastructure it created, because Soviet planners believed collective labor would convert native peoples into loyal members of the communist state (Teichmann 2007:513). Massive irrigation constructions were viewed as a way to achieve Soviet ideological goals, and planning for their longterm viability was neglected (Field 1954; O'Hara and Hannen 1999). The unsustainable state of irrigation agriculture in Central Asia today is a direct result of this ideologically-driven agricultural agenda (O'Hara 2000; O'Hara and Hannen 1999).

Pastoralism was also radically transformed by Soviet land policies in Inner Eurasia. As Chang (2015:24, 30) points out, these efforts were also ideologically motivated, informed by a Soviet view of nomadic societies as outside the Marxist evolutionary sequence, and therefore needing to be reformed through modernization. As a result, Kazakh and Turkmen nomads were forcibly sedentarized beginning in 1929, and their herds confiscated by the state, resulting in the death of over one and half million people. In place of the existing systems of transhumant rangeland production, collective farms based on sedentary husbandry were established, which relied heavily on water and fodder subsidies and export markets provided by the state. Mixed herd pastoralism largely disappeared, and animal husbandry in the collectives instead focused on a limited number of valued species, organized around rational use and optimum output models, with plan targets and yearly quotas imposed every year (Humphrey and Sneath 1999; Zanca 2000:1-2). While these changes did lead to new heights of profitability in, for example, karakul sheep farming, they also led to extreme pasture degradation as the land adjacent to the collective farms was overgrazed, and to a 'brain drain' of pastoral knowledge as experts and animals from across Inner Eurasia were centralized into collectives in a limited number of locations (Zanca 2000:3-4).

As agriculture came to dominate the landscapes of the modern Inner Eurasian oases, it dealt further blows to pastoral lifeways. The building of irrigation canals not only supported agricultural expansion, but was also a tactic that was used by Tsarist and Soviet authorities to subjugate and pacify nomadic groups. In the colonial era, canal-building was used to reclaim lands from nomads for agriculture, either enticing or forcing them to settle and engage in agricultural work (Irons 1974:652-3; Shioya 2014). Under Soviet rule, joining the collectives was technically voluntarily, but irrigation canals and agricultural fields played a pivotal role in restructuring the landscape against nomadic peoples, pushing them off their traditional grazing lands, degrading pasture resources, and forcing them to rely on state sources of water, food, and fodder. Later, largescale development programs, most notably the Virgin Lands program in the 1950s, concretized these schemes in the landscape by converting Kazakhstan's best summer pastures over to grain production, making these lands unfit for grazing and physically claiming them for state agriculture (Khazanov 2012:144-5). Ultimately, even later Soviet attempts that were meant to restore mobile pastoralism in Inner Eurasia could not succeed in this context of agricultural dominance. Zanca (2000:4-5) describes a pasture rotation initiative known as "System X" that was devised in Samarkand (Uzbekistan) in the 1970s to improve grazing practices, which failed not because of a lack of natural resources or institutional support from Moscow, but because local kolkhoz officials refused to dig the wells that were needed to re-establish shepherding routes across agricultural land.

\section{The Khorezm oasis}

How did the different social contexts of irrigation just described impact the development of irrigation in the Khorezm oasis, and what have been the different social and environmental outcomes? The Khorezm oasis (Figures 4 and 5) has been the site of some of the most extensive irrigation works in Inner Eurasia over the last three thousand years (Lewis 1966; Mukhamedjanov 1994:259). This irrigation has emerged time and again despite the volatility of Khorezm's water regime and an historical tendency for its canal systems to fail. There are multifaceted reasons for the tenacity of this irrigation, in which the social context has played a central role, helping to shape local people's decisions to irrigate, and leading them to develop different kinds of systems throughout history. 
The volatile Amu Darya delta

The Khorezm oasis is located in the Amu Darya delta, one of the most changeable deltas in the world (Asarin et al. 2010:120). With very little rainfall to carve permanent drainage patterns, its terrain is flat and smooth, leaving few topographic features in place to direct water flow in any particular direction. As a result, natural re-channeling of the delta's streams occurs repeatedly as sediments accumulate, and as water volume fluctuates due to evaporation loss and the seasonal inundation cycles of the river. These dynamics determine flow patterns across the delta, which can change dramatically and often abruptly. Artificial irrigation diverts water out into the desert and exposes it to additional evaporation loss, further accelerating these effects and changing both the direction and volume of water flows in the network.

The movements of the Amu Darya delta put human systems in continual peril. Throughout history, changes in the river's courses destroyed Khorezmian cities, villages, and irrigation systems, when habitation areas were either flooded or cut off from critical access to water. For example, the 10th century historian alBiruni describes how the Khorezmian town of al-Fir was "...broken and shattered by the Oxus [the Amu Darya], and was swept away piece by piece every year, till the last remains of it had disappeared..." (AlBiruni 1879:41). Le Strange (1930:447) also tells us that this city's second incarnation, the city of Kath, was likewise destroyed by the river, "...which ever and anon threw down different quarters of the city." In the early $20^{\text {th }}$ century, Olufsen (1911:238-239) documented how rapidly forming sand bars prevented the Amu Darya's waters from reaching the town of Kunye-Urgench, and had to be excavated to permit the water to flow;

As the arik [the canal] often becomes filled with sand, the boats sailing upon it are often seen lying on quite dry land, and it is only due to great exertions on the part of the inhabitants that lack of water is avoided at that time of the year when the amount of water in the Amu Darya decreases.

Since at least the $16^{\text {th }}$ century, local inhabitants were not only aware of these effects, but also that artificial irrigation could further accelerate change (Morgan and Coote 1885:70). Assuming that this local environmental knowledge was longstanding among Khorezm's inhabitants, a logical question arises: why continually pursue irrigation in such a volatile environmental setting, especially when your activities may be doomed to fail?

The ancient period, 7th century B.C. - 4th century A.D.

The first major phase of irrigation in the Khorezm oasis takes place in the 7th century B.C. - 4th century A.D. At this time, large networks of irrigation channels were built along the left bank tributaries of the Amu Darya (the Prisarykamysh delta, or western Khorezm), and the right bank tributaries (the lower Akcha Darya delta, or eastern Khorezm)(Andrianov 1969). Alongside irrigation, there was also a proliferation of new human settlements, represented by the appearance of many new monumental fortified sites, or qalas. Unfortified settlements, burial mounds (kurgans), and pastoral camps were also built at this time in different parts of the oasis (Tolstov 1948, 1962; Khozhaniyazov 2006; Negus Cleary 2015). In the 4th century A.D., nearly all of Khorezm's qalas, sites, and canals on both sides of the river were abandoned. Settlement mapping shows the waxing and waning of these occupation activities and suggests a connection with changes in the delta's channels (Boroffka 2010:287, figure 2; Brite 2011:172, figure 4.2).

What motivated Khorezm's ancient inhabitants to irrigate, what were the choices they made, and what were the consequences? These questions need to be considered in light of the social contexts of the time, which emphasized the integration of nomadic and sedentary ways of life. Multiple lines of evidence suggest that ancient Khorezmians perceived themselves this way, and they engaged in practices that reflected this mediated position. In art and ritual for example, the ancient Khorezmians depicted themselves as members of both the nomadic and sedentary worlds. Murals from the site of Akchakhan-kala (eastern Khorezm, ca. $1^{\text {st }}$ century B.C.) mix Iranian and steppic symbolism (Kidd 2011, 2012; Kidd and Betts 2010), using imagery such as a human-animal procession scene (Kidd 2011, 2012; Kidd, et al. 2012:82), Parthian-style torques on 
elite figures (Kidd 2011:249), and schematic portraiture (Kidd et al. 2012:82) to communicate a highly syncretic oasis-steppe ideology. Similarly, ancient Khorezmian burial styles combined the Mazdean, ossuary practices of sedentary groups with kurgan burial methods of the nomadic steppe at cemetery sites. As Negus Cleary (2015:142, 154) observes, the blending of these interment practices makes it hard to distinguish clear territorial boundaries between zones of pure "nomads" or pure "sedentists" in ancient Khorezm, and suggests the absence of a simple or static geography that separated these practices. In some cases in fact, intense integration between nomad/sedentist may have been especially emphasized (for example, at Bol'shoi Aibugirkala and the Kuiusai culture sites; Mambutallaev 1990; Negus Cleary 2015:154; Vainberg 1979).
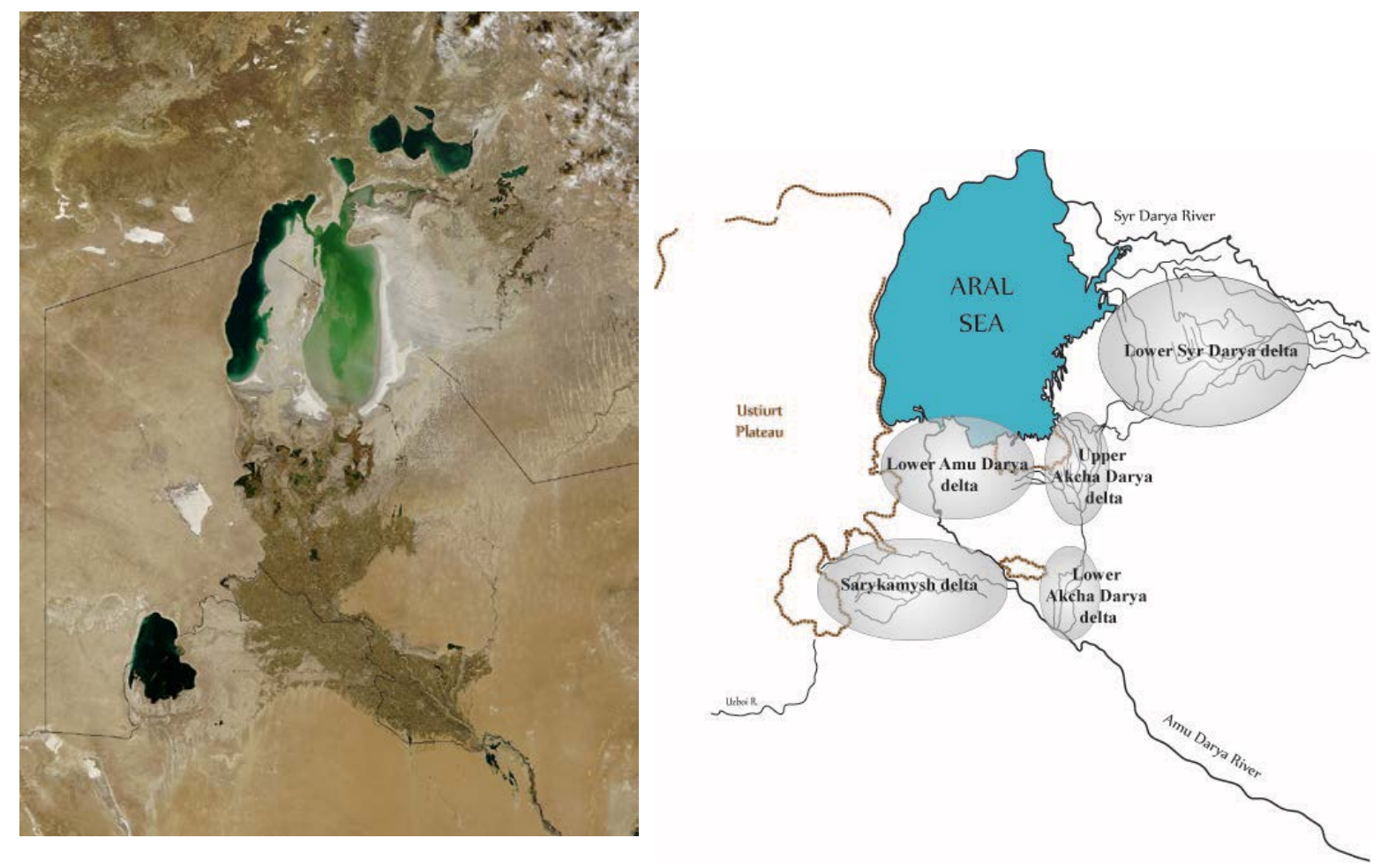

Figures 4 and 5: The Khorezm oasis, the Aral Sea, and the sub-regions of the Amu Darya delta. Source: NASA Visible Earth TerraMODIS, 2003 (left).

At a more pragmatic level, inhabitants of the Khorezm oasis in the 7th century B.C. - 4th century A.D. also lived integrated lives, practicing agriculture but also remaining at least partially reliant on rangeland livestock production. The major locus of human settlement at that time was the qala, a fortified enclosure site surrounded by a hinterland of short-lived occupations (Khozhaniyazov 2006; Nerazik 1976). The qalas were in some cases used as protective cattle corrals (Tolstov 1948:80), and generally exhibit a nomadic functionality that closely resembles the mobile pastoralist sites of Inner Eurasia's eastern steppe (Negus Cleary 2008, 2013, 2015; Honeychurch and Amartuvshin 2007; Rogers et al. 2005). Production practices at these sites included animal husbandry (Tsalkin 1952, 1966) and the cultivation of drought-tolerant crops (Brite and Marston 2013), whose low labor demands were elsewhere compatible with rangeland grazing (Chang et al. 2003; Motuzaite Motuzeviciute et al. 2015; Spengler et al. 2014:154-5). Other aspects of ancient Khorezmian agriculture, for example the cultivation of vineyards, melon patches, and fruit trees, similarly may suggest an emphasis on cropping strategies that made use of low intensity desert water harvesting techniques and would have allowed time for other production activities (Fleskens et al. 2007). 
The implication for irrigation practices in Khorezm in the ancient period was the design of systems that could address the needs of diverse, agropastoral producers, and which at a conceptual level reflected the intensely syncretic worldview of these inhabitants. This took different forms in different parts of the oasis. In western Khorezm, two large, wide canals, the Kunye Uaz and the Cherman-yab, were constructed in areas dominated by pastoral sites, where only limited traces of ancient agriculture have been found despite intensive surveys (Andrianov 1969:168; Negus Cleary 2015; Tsvetsinskaya et al. 2002:369-70). The larger of these canals, the Kunye Uaz, stretched for $50 \mathrm{~km}$ and was on average 70-75 m wide (Andrianov 1969:156). It was thus a significant investment in water infrastructure, and yet it does not appear to have supported an intensive and expansive regime of agricultural production. Tsvetsinskaya et al. (2002:369-70) describe a "subrectangular" canal system in this part of the oasis, in which channels were dug at right angles to connect parallel streams, creating an ecologically balanced terrain with a constantly flowing source of water (see also Andrianov 1969:164, 168, and figure 45). Rather than transporting water to the terminus of a canal to deposit it on a field, this system may have been designed to avoid these preferential water allocations and to instead supply water equally for livestock grazing, inundation for fodder production, and some small-scale agriculture.

Other parts of the oasis were more intensively cultivated. Eastern Khorezm is considered the region's ancient agricultural "heartland" (Tolstov 1948, 1962), where numerous, dendritic networks of deep, narrow, and long canals were dug to supply water to a great number of agricultural fields. These fields were used to cultivate cereals including wheat, barley, and millet, and to support vineyards, melon patches and fruit orchards, and possibly, cotton fields (Andrianov 1995:108; Brite and Marston 2013). In an effort to fight the natural dynamics of the Amu Darya delta, inhabitants repeatedly moved the headwaters of these canals upstream, and they later redesigned entire systems, narrowing canal widths, extending their "tails," and adding more but shorter lateral branches (Andrianov 1969:136-7). These changes suggest a commitment to irrigation strategies over time, with a focus on continually rebuilding the networks to enhance water distribution for agricultural use (Andrianov 1969:117, figure 32, 120, figure 34; comments, see Brite 2011:116, 139-40, and figure 3.7; on chronological issues, see Brite 2011:135-6).

How are we to make sense of the different, ancient irrigation system designs found in western versus eastern Khorezm? Both the motivations for, and the consequences of these designs can again be understood with reference to the social context, in this case the political and economic climate in the Khorezm oasis in ancient times that structured nomad/sedentist interactions. It was common in ancient Inner Eurasia for the elite class to derive either directly or indirectly from the nomadic steppe, and to retain a semi-nomadic lifestyle and tribal forms of political authority, even while overseeing agrarian lands (Chang 2008; De la Vassiere 2005:167-168; Grinberg 2013; Lamberg-Karlovsky 1994; Stride et al. 2009:81-3; Sinopoli 1994; Sneath 2007). Lamberg-Karlovsky (1994) argues that this nomadic political culture, known as the khanate system, strongly influenced the development of eastern Khorezm's irrigation systems, because local khans would have competed over claims to land and water resources to be used as tribute to pay tribal members. This situation helps to explain why many of eastern Khorezm's qala sites derived water independently from the Amu Darya via their own canal branches, why the canals show repeated investments in reconstruction, and also why these sites and canals were often placed on the boundaries of the oasis (Khozhaniyazov 2006) -they were attempts by the khans to establish their claims to land and water, and to compete for the right to mediate trade along the borders of the oasis (Kidd 2011:239), through direct alterations of the resource landscape.

A somewhat different political and economic dynamic must have existed in western Khorezm, as the settlement and canal systems west of the Amu Darya do not exhibit these same patterns. Here, small canals were united over time across agricultural and pastoral zones to form single, massive systems (Lewis 1966:484; Tsvetsinskaya et al. 2002:368-370). This pattern is similar to that described by Stride and colleagues (2009) along the Dargom in ancient Sogdiana (see above), and in that context, consensus, rather than competition, may have been more of a driving factor in irrigation development. A consensus model in western Khorezm may help to explain the 'subrectangular' system design, and also may reflect the more intense synergies between nomadic and sedentary cultures observed in this part of the oasis (Negus Cleary 2015; Vainberg 1979). 
Finally, the archaeological record makes clear that the irrigation practices of the ancient period met a definitive and catastrophic end in the 4th century A.D., when the sites and canals of the Khorezm oasis are almost completely abandoned. How did the pre-existing social factors in Khorezm at that time, namely, consensus/competition between nomadic and sedentary cultures, play into these changes? In the contexts of consensus in western Khorezm, shared water infrastructure may have developed as one material result of a much broader set of social compacts, which evolved to enable greater resiliency in an unstable environment. The need for exchanges that 'tied' the landscape together, both figuratively and literally, would probably have outweighed concerns for land degradation or impacts on the hydrological network of the Amu Darya delta (if these were perceived; see Sala 2012:69-70); moreover, the canals themselves may have been viewed as attempts to stave off the impacts of environmental change, functioning as a mechanism to bring diverse producers together. In the competitive contexts of eastern Khorezm, irrigation canals were possibly as much political propaganda as they were production resources. Intense competition between khans and their need for continually expanding land enticements may have simply overridden other environmental concerns when opportunities for political consolidation arose. Khans who maintained their links with the steppe world, or who retained privileged access to alternative subsistence practices (Allsen 2006), may have had a particularly short-sighted approach to the construction of these features, and/or a lack of environmental knowledge, that led them to be less concerned with potential irrigation failures.

\section{The modern period, late 19th century - present}

The most recent period of irrigation development in the Khorezm oasis has been dramatic, with irrigated land increasing over two and half times its pre-colonial extents in the last century. The vast majority of this expansion has focused on cotton production, with cotton farming accounting for nearly half of all irrigated land up to the fall of the Soviet Union (Micklin 2014:211). It is by now a well-established fact that modern cotton farming in Khorezm is a major contributor to land salinization, water logging, declining human health, and the desiccation of the Aral Sea (Glantz 1999; Micklin 1988, 1992, 2007, 2010), impacts that Soviet planners appear to have known about at least as early as mid-century (Field 1954:539-40). This raises inevitable questions about why irrigation expanded so dramatically in this period in this way, and why people have continued to invest in these systems, in the face of unsustainable conditions.

The modern period of irrigation expansion in the Khorezm oasis has been tied to the ideological, political, and economic goals of foreign empires. Locally, this development focused almost exclusively on expanding cotton agriculture to support the creation of an independent textile economy in Russian territory. Tsarist entrepreneurs laid the groundwork by establishing their own, large cotton plantations; they also encouraged local Khorezmian farmers to grow cotton by providing them with access to foreign markets, capital investment, and high yield seed varieties (Thompstone 1995). After the Bolshevik Revolution, cotton production was directly mandated by the state, with specific production quotas for the provinces set each season. Soviet authorities invested significant resources to develop Khorezm's cotton monoculture, providing new irrigation infrastructure, heavy machinery, and bureaucratic oversight to convert the entire region over to large, collective farms that could produce the high quality raw cotton needed for their textile industry. Knowledge about local environmental circumstances and concerns for the long-term vitality of local production systems took a back seat to the state's economic targets under the Five Year Plans and other planning measures (Micklin 2014:215).

Irrigation and farming practices that exist in Khorezm today are largely a legacy of these policies of the modern period, which are pernicious but hard to change because they have had lasting impacts on Khorezmian society. For example, when Tsarist entrepreneurs established large cotton plantations in Khorezm, they also negotiated new systems of land tenure that created property rights that privileged cotton production over other forms of land use (Conti 2004:71). Part of these conversions included the confiscation of rangelands, which were permanently reclassified as agrarian land when they were brought under cultivation, transferring their ownership over to regional authorities (Conti 2004:71-2). Under Soviet rule, control of Khorezm's water was centralized, so that information about water and decisions about water allocation no longer rested with local communities (O'Hara and Hannen 1999:27). Soviet engineers built long 
mega-canals with advanced headworks that channeled water directly from the main river; these greatly improved system efficiency and supported high yield production on the large collective farms, but they also cut off the small channels with independent control mechanisms that previously provided water to the villages. The result was that villagers could no longer represent or address their own water needs, and they no longer even knew from where their water came (Conti 2004:136-8). New social relations of production were in these ways not only imposed from outside by governmental institutions, but they were also permanently embedded in the Khorezmian landscape through the reshaping of farmland and irrigation canals.

The collapse of the Soviet Union in 1991 created independent states out of the Central Asian republics but did not transform these pre-existing agricultural systems. As a result, liberalization has evolved in the post-Soviet space in uneven ways, and has had unforeseen and unintended consequences for Khorezmian irrigation agriculture (Trevisani 2007, 2010). As a former Soviet republic whose economy had been almost solely devoted to cotton production, Uzbekistan's only option for generating national revenue has been to continue cotton farming, using the infrastructure and market resources it inherited from its Soviet predecessors. Thus, in regions like Khorezm the command economy lives on under the guise of new liberalizations. The state still mandates cotton production among farmers who lease land independently from the state (known as the fermer system), and these central demands for cotton shape all other, down-the-line decisions that farmers make about which crops to grow and how to use water. In order to gain access to private landholdings, farmers wishing to establishing a fermer enterprise must officially commit to growing cotton on $60 \%$ of their land (wheat is another state ordered crop that has been prioritized since transition, under similar conditions; Veldwisch and Spoor 2008). This 'private' cotton farming is heavily subsidized and prices are set by the government such that farmers receive little if any monetary profit. What they do accrue, however, are property rights and social capital that permit them to sow the remainder of the land to other commercial crops (Veldwisch and Spoor 2008:439). Landless dekhan peasants similarly earn rights to commercial sharecropping by contracting their labor to the fermers to help with cotton production. The result is that growing cotton in Khorezm today has become the sole pathway to producing any other kind of agricultural crop.

What makes up the other $40 \%$ of the crop assemblage that farmers in Khorezm choose to grow? In household garden plots, Khorezmians grow a relatively wide range of grains, fruits and vegetables for personal consumption, but the overwhelming majority of the remainder of their commercial production focuses on rice, to which they devote nearly $10 \%$ of all irrigated land in the oasis (Bobojonov et al. 2013:798). Rice is an exceptionally water-thirsty crop whose production at first glance makes little sense in a desert oasis experiencing an ongoing water crisis. Rice, however, provides a number of important benefits to Khorezmian farmers in the post-Soviet, liberalized economic and degraded environmental contexts in which they operate. First, farmers have access to robust markets in which to sell their rice. As a legacy of the Soviet economic system, there is an active, accessible export market for rice that does not exist for other crops (Bobojonov et al. 2013:803-6), and Khorezmian farmers also have the opportunity to sell rice for cash in local markets, or even use it as direct currency in local exchanges (Veldwisch and Spoor 2008:442-3). Growing rice in Khorezm is therefore like growing cash itself. Second, though broadly speaking the wet, paddy agriculture that rice requires fits poorly with the water provisions of a desert oasis, rice does in fact work well environmentally in a context where new agricultural land is being reclaimed from desiccated desert lakes. This lake land is too saline for cotton or wheat, but can work well for rice cultivation. Rice can also be grown in rotation with wheat in Khorezm, making it possible for fermers to meet state demands while also providing themselves with commercial profits (Veldwisch and Spoor 2008:440).

Another important factor that influences current environmental decision-making in Khorezm are the cultural values that have evolved over 70 years of being incorporated in the Soviet Union. The robust local market for rice exists in large part because this grain, which had previously been eaten only by wealthy elites, became a widely consumed cultural food item during the Soviet Union's era of prosperity following World War II (Zanca 2011:92-3). As a food eaten regularly by the masses and at weddings, rice has become an important symbol of the well-being of Khorezmian families and communities (G. Botirova, personal communication). Similarly, cotton is a core part of local culture and rural identity. An individual's continued commitment to cotton production is interpreted as a statement about their state loyalty (Oberkircher and 
Hornidge 2011:409, footnote 6). Materially, Soviet propaganda embedded the image of the cotton blossom in all manner of local Khorezmian culture, which can still be encountered today all over Khorezmian homes, towns, and villages, including on teapots, dinnerware, sidewalk gates, and even lampposts (Figure 6).

Likewise, a whole set of cultural values have emerged out of people's material engagements with Soviet-era irrigation canals, which continue to have a direct impact on how Khorezmians use water. As Oberkircher and Hornidge (2011) report in their ethnographic studies, the ongoing presence of large canals encourages local farmers to equate having "enough" water with the ability to fill them up and supply water to the entire network. The transboundary character of Khorezm's centralized irrigation system, in which large canals divert water directly from the river, and whose supplies are controlled by large dams in other, upstream countries, also lead local farmers to assume water management is the state's responsibility. Water "saving" is thus seen as a governmental act that must occur outside the context of local farm activities, when authorities make their annual decisions about regional crop and water requirements. 'Wasting' water is similarly not defined as taking too much from the river, but rather not using up everything that is rightfully allocated to you by the central government. In this context of centralization, an individual's ability to get and use large amounts of water has become an important symbol of prestige in the bureaucratic hierarchy, such that water saving is nothing for a Khorezmian farmer to aspire to (Oberkircher and Hornidge 2011:411).

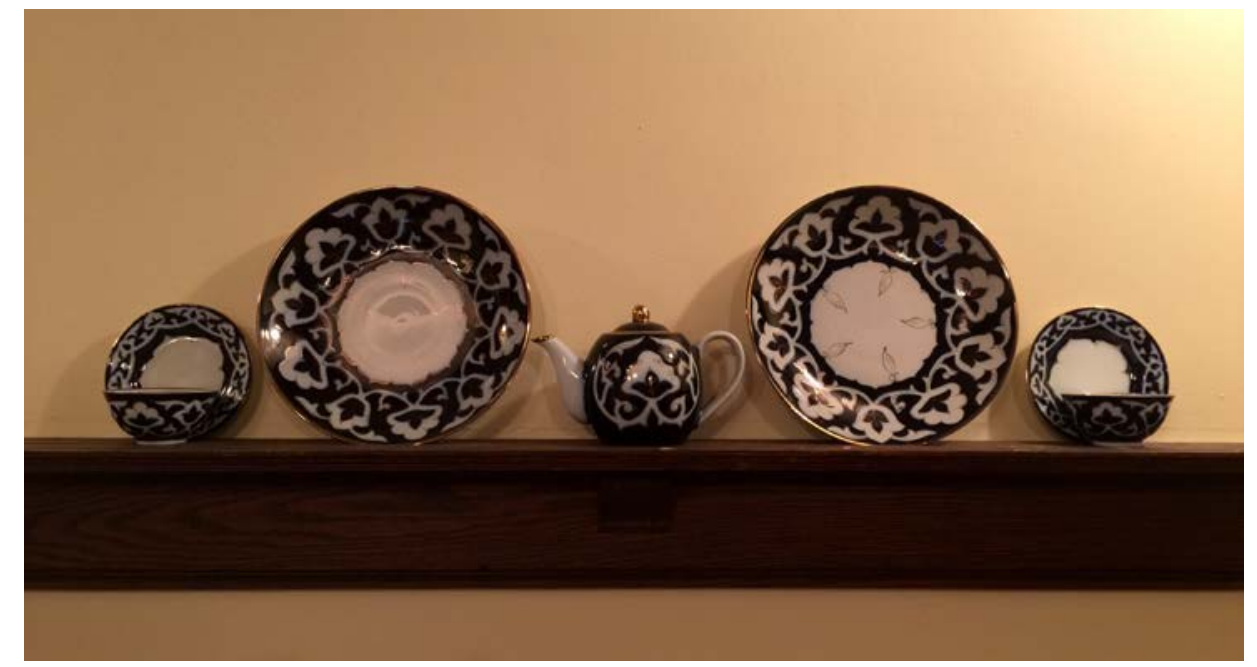

Figure 6: Ceramics from the Khorezm oasis with cotton blossom motif.

\section{Discussion}

This article argues that a contextualized perspective can help us to better understand the decisions that lead to irrigation collapse in the Khorezm oasis. From a distance, choices to irrigate in such an unstable environment seem both quixotic and maladaptive. A deeper examination of the influences, principles, and practices that guided these choices, however, helps to place human decision-making within an intelligible frame. Comparing two phenomena of collapse, the rise and fall of Khorezmian irrigation in the 7th century B.C. - 4th century A.D. and the most recent activities over the last two centuries, we can begin to see how vastly different historical and social conditions impact irrigation trajectories. More than just an attempt to exploit the natural resources of the oasis, Khorezm's irrigation canals are cultural products that reflect the needs and desires of the people who build them, in one case underpinning ancient Khorezmian attempts to integrate agricultural and pastoral ways of life, and in the other materializing the agendas of Soviet modernization.

Scholars interested in the topic have repeatedly questioned whether Khorezm's irrigation collapses were caused by natural or anthropogenic factors (Cretaux et al. 2013). The fact that collapse occurred (or is occurring) in each period, irrespective of significant differences in population, irrigation technology, and 
design, suggests that systemic failures may be inevitable in the ever-changing Amu Darya delta. Certainly, this is the opinion of the oasis' current and past inhabitants (Morgan and Coote 1885:70; Oberkircher and Hornidge 2011:403). Regardless, a more important point may be that the different cultures of irrigation that have evolved in Khorezm over the last three millennia have each engaged in their own dialectic with the delta's volatility, resulting in far different outcomes for inhabitants through time. In the ancient case, people built canals but also maintained a level of mobility in their cultural practices, either directly through engagements with rangeland pastoralism, or indirectly by placing a high social value on nomadism. When deleterious changes were encountered that undermined their irrigation systems, a plausible response that diverse communities shared was to move. The result was a wide-scale abandonment of sites and canals across the Khorezm oasis in the 4th century A.D. By contrast, modern irrigation canals are a component of a much more sedentarized culture, in which economic gains are sought through continued investment in the intensive exploitation of the oasis landscape. The promise of a better future for the nation and its people are rooted in the continual use of Khorezm's agricultural resources, a worldview that keeps farmers on the land and keeps them growing commercially desirable and resource-intensive crops. As this system comes up against the natural limitations of the oasis, inhabitants find themselves with little capacity to envision or implement a more profitable way forward. The result is more intense encounters with environmental change, for both people and nature.

Differences in the technological features of Khorezm's ancient and modern canals derived from these differences in cultural practices, and they also likely emerged from encounters with the natural oasis environment. For example, the 'subrectangular' irrigation system in ancient western Khorezm may have been designed to allocate water equitably to a diverse landscape of users, and it also capitalized on the natural, parallel-running streams of the Prisarykamysh delta. While these more pragmatic aspects of technological design should not be overlooked, it is important to recognize that they may be difficult if not impossible to untangle from the cultural lenses through which people viewed them (Dobres 2000; Schiffer and Skibo 1997). Cultural perceptions of need, past experiences of what works best, and the constraints and opportunities at any given time for technological development all influenced people's decisions about how to design these systems, and how to best address the natural challenges they faced with irrigation canals. The technological features of canal design that have materialized are thus socio-natural objects (Linton 2008, 2014; Swyngedouw 1999, 2009, 2015). Their functional operation has been determined by some visible but also many unseen social components, such as regular acts of social cooperation to clean the canals and keep them flowing, the coordination of nighttime watering to reduce evapotranspiration, or clandestine water withdrawals, which make it impossible to separate the material functions of the canals from the social contexts in which they were activated.

Many centuries intervened between the end of ancient irrigation in the 4th century A.D. and the modern period, in which many more systems of irrigation were established and abandoned in the Khorezm oasis. These too were cultural products that were specific to their time. Conti (2004) makes the point, for example, that irrigation and land tenure systems in the era of the Khivan Khanate (16th -19th centuries) can only be understood in relation to late Persianate Islamic concepts of property and shared social obligation. Rules in the Khanate that determined how land was allocated to farming and pastoralism, and how systems of water allocation were to be directed by local officials known as mirabs, all extended from Islamic interpretations that deemed resources as given by God, to be held in trust by leaders with direct responsibilities to the ummah (Conti 2004:44-5). Religious, political, economic, and cultural concepts undoubtedly guided land and water practices during other phases of Khorezmian history in similar ways, though there are significantly fewer textual sources to reveal the details of these relationships.

In studies of the Aral Sea disaster, scholars have repeatedly described institutions such as the mirab as they try to understand irrigation problems in this region today, in a search for more sustainable ways to manage water resources (O'Hara 2000:378-9; O'Hara and Hannan 1999:24). In these instances, the mirabs have sometimes been compared to water user associations (WUA), a type of village-level water organization highly valued by the global development community (Conti 2004; Wegerich 2000, 2010). What the above examination shows, however, is that we should be careful not to compress the phases of history, and to recognize that practices like the mirab office evolved and were sustained in Khorezm by a socio-natural 
landscape that no longer exists. In addition, every irrigation system that has emerged in Khorezm over the past three millennia has had consequences for oasis inhabitants, both positive and negative, and each was ultimately unsustainable in some way that led to dramatic anthropogenic change. We would be remiss to assume there was some 'traditional' form of irrigation that once existed in the Khorezm oasis, some pristine state of balance between people and resources that modernity has only recently destroyed, and which we might hope to restore. Likewise, it is imperative that we recognize that any solutions to the current problems that may be sought, whether WUAs or otherwise, are equally cultural products of their time that reflect the perceptions of the people who design them, and which operate within, and must confront, a quasi-natural social reality.

Does this mean that the prospects for post-Soviet Khorezm are grim? No one who has studied the problems in this region would say that the current outlook is very positive for its people or environment. As of 2010, the Aral Sea had lost 91\% of its previous total volume and has essentially disappeared (Gaybullaev et al. 2012:285). Inhabitants are facing deteriorating health as a result of the salts and pesticides that have been released into the air, and their opportunities for prosperous livelihoods are diminishing. History reveals, however, that people have found innumerable ways to live in the Khorezm oasis, and their continual presence in times good and bad suggests that this is unlikely to change any time soon. Contextualized interpretations of past collapses show that we must take our cues about how to productively move forward from an intimate familiarity with the current challenges people face, and with the recognition that the outcomes of our actions will be as much cultural products as our decisions.

\section{Concluding remarks}

Irrigation canals are not just conduits for agriculture. Irrigation networks tie diverse communities of water users together across a landscape, providing access to a critical resource that is utilized by everyone, and in which everyone has a stake (Meinzen-Dick 1997; Meinzen-Dick and van der Hoek 2001). Irrigation systems also balance power among users in different ways. Even seemingly mundane changes to features like canal lining, headwater intake devices, or groundwater sourcing can have dramatic effects on social relationships, because irrigation systems are born out of particular social conditions and they are structured to interface with them (Lam 1996; Ostrom and Gardner 1993). This is why changes to human water systems are profound; altering how people acquire water, and how their neighbors acquire it, can change the entire fabric of social relations. To assume that irrigation canals are directly comparable across different social contexts obscures the many cultural perceptions and behaviors that shape their development. Karl Wittfogel (1957) was not wrong in seeing irrigation as representative of society and power, but he oversimplified these entanglements, failing to look at the many complexities that shape these systems at highly localized scales (Hunt and Hunt et al. 1976).

The natural world is likewise caught up within these cultural systems of irrigation. Nature, as humans experience it, is a cyborg thing, made of material objects but shaped by human interventions (Swyngedouw 1999, 2009, 2015). When scientific studies describe a shrinking Aral Sea, they are at best describing a hydrosocial space (Linton 2008, 2014), which has formed from the interactions between nature, society, and a society's irrigation canals within a specific timeframe. Time-lapsed maps and satellite imagery of the Aral Sea consistently obscure this broader picture by leaving out the human landscapes of the Khorezm oasis (Figure 7), making it harder to understand the complex, contextually-derived circumstances that lead to environmental change. Instead, we should attempt to view each of the Aral Sea's recessions as a connected, social whole that is not abstracted from surrounding peoples and their historical circumstances, but rather understood through direct reference to them.

Finally, by applying contextual inquiry to the study of two examples, one past and the other present, this article has shown how political ecology can be as relevant to archaeology as it is to cultural anthropology. The insights of political ecology, especially those that concern the socially contextualized nature of environmental behavior, are not exclusively applicable to the modern or post-colonial world, but just as equally adhere in the ancient past. Thinking about these ancient political ecologies can improve the interpretive power of both anthropological and archaeological research, by encouraging us away from views 
of past eras as timeless traditions of humans-in-nature irreparably altered by modernity, and leading us towards more critical perspectives that see the phases of history as a succession of socio-natural realities that differed across time.

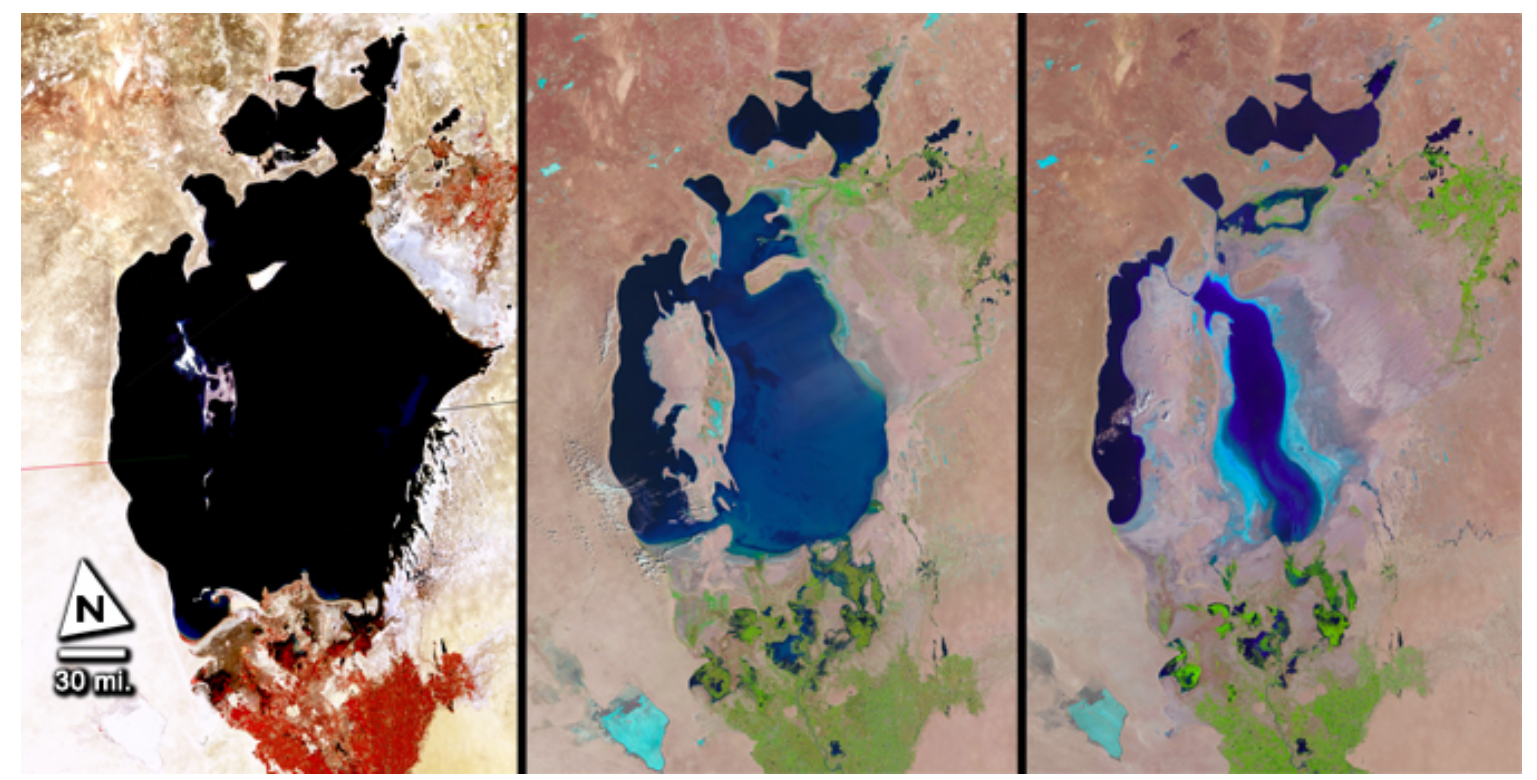

Figure 7. Landsat 8 images of a shrinking Aral Sea, as shown on NASA's website, http://www.nasa.gov/mission_pages/landsat/news/40th-top10-aralsea.html. Images taken in 1977, 1998, and 2010. Source: USGS EROS data center.

\section{References}

Al-Biruni, A.R. 1879. The chronology of ancient nations. E. Sachau (transl.). London: William H. Allen and Company.

Allsen, T.T. 2006. The royal hunt in Eurasian history. Philadelphia, PA: University of Pennsylvania Press.

Andrianov, B.V. 1969. Drevnie orositel'niye sistemy Priaral'ia (v sviazi s istorier vozniknoveniia i razvitiia oroshaemogo zemledeliia). Moscow: Nauka.

Andrianov, B.V. 1995. The history of economic development in the Aral region and its influence on the environment. GeoJournal 35(1): 11-16.

Asarin, A.E., V.I. Kravtsova, and V.N. Mikhailov. 2010. Amudarya and Syrdarya rivers and their deltas. In A.G.Kostianoy and A.N.Kosarev (eds.) The Aral Sea environment. Heidelberg: Springer. Pp101-121.

Betts, A.V.G. 2006. Chorasmians, Central Asian nomads and Chorasmian military architecture. In G.Khozhaniyazov (ed.) The military architecture of ancient Chorasmia (6th century B.C.- 4th century A.D.). Paris: Editions de Boccard. Pp131-155.

Betts, A.V.G., V.N. Yagodin, F. Grenet, F. Kidd, M. Minardi, M. Bonnat, and S. Khashimov. Forthcoming. The Akchakhan-kala wall paintings: new perspectives on kingship and religion in ancient Chorasmia. Under review for Asian Art and Archaeology.

Bobojonov, I., J.P. Lamers, N. Djanibekov, N. Ibragimov, T. Begdullaeva, A.K. Ergashev, K. Kienzler, R. Eshchanov, A. Rakhimov, J. Ruzimov, and C. Martius. 2013. Options and constraints for crop diversification: a case study in sustainable agriculture in Uzbekistan. Agroecology and Sustainable Food Systems 37(7): 788-811. 
Boomer, I., N. Aladin, I. Plotnikov, and R. Whatley. 2000. Paleolimnology of the Aral Sea: a review. Quaternary Sciences Reviews 19: 1259-1278.

Boomer, I., B. Wünnemann, A.W. Mackay, P. Austin, P. Sorrel, C. Reinhardt, D. Keyser, F. Guichard, and M. Fontugne. 2009. Advances in understanding the late Holocene history of the Aral Sea region. Quarternary International 194: 79-90.

Boroffka, N.G. 2010. Archaeology and its relevance to climate and water level changes: a review. In A.G.Kostianoy and A.N.Kosarev (eds.) The Aral Sea environment. Heidelberg: Springer. Pp283-303.

Boroffka, N.G., H. Oberhänsli, G.A. Achatov, N.V. Aladin, K.M. Baipakov, A. Erzhanova, A. Hörnig, S. Krivonogov, D.A. Lobas, T.V. Savel'eva, B. Wünnemann. 2005. Human settlements on the northern shores of Lake Aral and water level changes. Mitigation and Adaptation Strategies for Global Change 10: 71-85.

Boroffka, N.V., H. Oberhänsli, P. Sorrel, F. Demory, C. Reinhardt, B. Wünnemann, K. Alimov, S. Baratov, K. Rakhimov, N. Saparov, T. Shirinov, S. Krivonogov, and U. Röhl. 2006. Archaeology and climate: settlement and lake-level changes at the Aral Sea. Geoarchaeology 21(7): 721-734.

Brite, E.B. 2011. The archaeology of the Aral Sea crisis: environmental change and human adaptation in the Khorezm region of Uzbekistan, ca. AD 300-800. Ph.D. dissertation. Los Angeles, USA: University of California.

Brite, E.B. and J. Marston. 2013. Environmental change, agricultural innovation, and the spread of cotton agriculture in the Old World. Journal of Anthropological Archaeology 32(1): 39-53.

Brite, E.B. 2014. Mobility in the Central Asian oasis states: archaeological evidence from Antique Khorezm. Bulletin of the International Institute of Central Asian Studies 18: 3-25.

Chang, C. 2008. Mobility and sedentism of the Iron Age agro-pastoralists of southeast Kazakhstan. In W.Wendrich and H.Bernard (eds.) The archaeology of mobility: Old World and New World nomadism. Los Angeles: Cotsen Institute of Archaeology. Pp329-342.

Chang, C. 2015. The study of nomads in the Republic of Kazakhstan. In P.N.Kardulias (ed.) The ecology of pastoralism. Boulder: University of Colorado Press. Pp17-40.

Chang, C., N. Benecke, F.P. Grigoriev, A.M. Rosen, and P.A. Tourtellotte. 2003. Iron Age society and chronology in south-east Kazakhstan. Antiquity 77(296): 298-312.

Clarke, D., R. Sala, J.-M. Deom, and E. Meseth. 2005. Reconstructing irrigation at Otrar oasis, Kazakhstan 800-1700AD. Irrigation and Drainage 54(4): 375-388.

Conti, P. J. 2004. The ties that bind: the traditional irrigation systems of Uzbekistan, social capital, and implications for current, successful management. Masters thesis. Missoula, USA: University of Montana.

Cretaux, J-F., R. Letolle, and M. Bergé-Nguyen. 2013. History of Aral Sea level variability and current scientific debates. Global and Planetary Change 110(Part A): 99-113.

De la Vaissiere, E. 2005. Sogdian traders: a history. J. Ward (transl.). Leiden: Brill.

Dobres, M. 2000. Technology and social agency: outlining a practice framework for archaeology. Oxford: Blackwell.

Field, N.C. 1954. The Amu Darya: a study in resource geography. Geographical Review 44(4): 528-542.

Fleskens, L., A. Ataev, B. Mamedov, and W.P. Spaan. 2007. Desert water harvesting from takyr surfaces: assessing the potential of traditional and experimental technologies in the Karakum. Land Degradation and Development 18(1): 17-39.

Gaybullaev, B., S.-C. Chen, and D. Gaybullaev. 2012. Changes in the water volume of the Aral Sea after 1960. Applied Water Science 2: 285-291.

Gintzburger, G., K.N. Toderich, B.K. Mardonov, and M.M. Mahmudov. 2003. Rangelands of the arid and semi-arid zones in Uzbekistan. Paris: ICARDA. introduction

Glantz, M.H. (ed.). 1999. Creeping environmental problems and sustainable development in the Aral Sea. Cambridge: Cambridge University Press. 
Gorbunova, N.G. 1986. The culture of ancient Ferghana: VI century B.C. - VI century A.D. A.P.Andryushkin (transl.). Great Britain: BAR International Series 281.

Gorbunova, N.G. 1992. Early nomadic pastoral tribes in Soviet Central Asia during the first half of the first millennium A.D. In G.Seaman (ed.) Foundations of empire, archaeology and art of the Eurasian steppes. Los Angeles: Ethnographics Press. Pp31-45.

Greenberg, J.B. and T.K. Park. 1994. Political ecology. Journal of Political Ecology 1: 1-12.

Grinberg, L. 2013. "Is this city yours or mine?" Political sovereignty and Eurasian urban centers in the ninth through the twelfth centuries. Comparative Studies in Society and History 55(4): 895-921.

Gul'yamov, Ia.G. 1957. Istoriia orosheniia Khorezma c drevneishikh vremen do nashikh dnei. Tashkent: Izdatel'stvo Nauka Uzbekskoi SSR.

Harris, D.R. 2010. Origins of agriculture in western Central Asia: an environmental-archaeological study. Philadelphia: University of Pennsylvania Museum of Archaeology and Anthropology.

Honeychurch, W. and C. Amartuvshin. 2007. Hinterlands, urban centers, and mobile settings: the "new" Old World archaeology from the Eurasian steppe. Asian Perspectives 46(1): 36-64.

Humphrey, C. and D. Sneath. 1999. The end of nomadism? Society, state, and the environment in Inner Eurasia. Durham, NC: Duke University Press.

Hunt, R.C. and E. Hunt. 1976. Canal irrigation and local social organization [and comments and reply]. Current Anthropology 17(3): 389-411.

Irons, W. 1974. Nomadism as a political adaptation: the case of the Yomut Turkmen. American Ethnologist 1(4): 635-658.

Khazanov, A.M. 2012. Pastoralism and property relations in contemporary Kazakhstan. In A.Khazanov and G.Schlee (eds.) Who owns the stock? Collective and multiple property rights in animals. New York: Berghahn. Pp141-158.

Khozhaniyazov, G. 2006. The military architecture of ancient Chorasmia (6th century B.C. - 4th century A.D.). S.W. Helms (transl.). Paris: Editions de Boccard.

Kidd, F. 2012. The procession scene at Akchakhan-kala. Parthica 14: 65-88.

Kidd, F. 2011. Complex connections: figurative art from Akchakhan-kala and the problematic question of relations between Khorezm and Parthia. Topoi 17: 229-276.

Kidd, F. and A.V.G. Betts. 2010. Entre le flueve et la steppe: nouvelles perspectives sur le Khorezm ancien. Comptes Rendus des Seances de l'Academie des Inscriptions at Belles Lettres 2: 637-686.

Kidd, F., M.N. Cleary, and E.B. Brite. 2012. Public vs. private: perspectives on the communication of power in ancient Chorasmia. In C.W.Hartley, G. B.Yazicioğlu, and A.T.Smith (eds.) The archaeology of power and politics in Eurasia: regimes and revolutions. Cambridge: Cambridge University Press. Pp91-121.

Kidd, F., M.N. Cleary, V.N. Yagodin, A.V.G. Betts and E.B. Brite. 2008 [2004]. Ancient Chorasmian mural art. Bulletin of the Asia Institute 18: 69-95.

Lam, W.F. 1996. Improving the performance of small-scale irrigation systems: the effects of technological investments and governance structure on irrigation performance in Nepal. World Development 24(8): 1301-1315.

Lamberg-Karlovsky, C.C. 1994. The Bronze Age khanates of Central Asia. Antiquity 68: 398-406.

Le Strange, G. 1930. The lands of the eastern Caliphate: Mesopotamia, Persia, and Central Asia from the Moslem conquest to the time of Timur. Cambridge: Cambridge University Press.

Letolle, R., P. Micklin, N. Aladin and I. Plotnikov. 2007. Uzboy and the Aral regressions: a hydrological approach. Quaternary International 173-174: 125-136.

Levina, L.M. 1996. Etnokul'turnaia istoriia vostochnogo Priaral'ia. Moscow: Izdatel'skaia Firma Vostochnaia Literatura.

Lewis, R.A. 1966. Early irrigation in west Turkestan. Annals of the Association of American Geographers 56: 467-491. 
Linton, J. 2008. Is the hydrologic cycle sustainable? A historical-geographical critique of a modern concept. Annals of the Association of American Geographers 98(3): 630-649.

Linton, J. 2014. Modern water and its discontents: a history of hydrosocial renewal. WIREs Water 1: 111120.

Maev, E.G., S.A. Maeva, and Yu. A. Karpitshev. 1991. Aralskoe More v Golotsene (po materialam izucheniya razrezov donnykh otlozhenii). In B.V.Andrianov (ed.) Aralskii krisis: istorikogeograficheskaya retrospektiva. Moscow: Institut Ethnologischeski Anthropologiya Akademia Nauk SSSR. Pp76-86.

Mambutallaev, M. 1990. Gorodische Bol'shaya Aibugyr-kala (raskopki 1976-1977 i 1981 godi). Arkheologiya Priaral'ya 4: 91-131.

McCay, B.J. 2008. An intellectual history of ecological anthropology. In B.B.Walters, B.J.McCay, P.West, and S.Lees (eds.) Against the grain: the Vayda tradition in human ecology and ecological anthropology. Lanham, MD: AltaMira Press. Pp11-26.

Meinzen-Dick, R. 1997. Valuing the multiple uses of irrigation water. In M.Kay, T.Franks, and L.Smith (eds.) Water: economics, management, and demand. London: E \& FN Spon. Pp47-54.

Meinzen-Dick, R. and W. van der Hoek. 2001. Multiple uses of water in irrigated areas. Irrigation and Drainage Systems 15.2 (2001): 93-98.

Micklin, P. 1988. The dessication of the Aral Sea: a water management disaster in the Soviet Union. Science 241(4870): 1170-1176.

Micklin, P. 1992. The Aral Sea crisis: introduction to the special issue. Post-Soviet Geography 33(5): 269282.

Micklin, P. 2007. The Aral Sea disaster. Annual Review of Earth and Planetary Science 35: 47-72.

Micklin, P. 2010. The past, present, and future of the Aral Sea. Lakes and Reservoirs: Research and Management 15(3): 193-213.

Micklin, P. 2014. Irrigation in the Aral Sea Basin. In P. Micklin (ed.) The Aral Sea. Berlin: Springer. Pp207232.

Miller, N. 1999. Agricultural development in western Central Asia in the Chalcolithic and Bronze Ages. Vegetation History and Archaeobotany 8: 13-19.

Moore, K., N.F. Miller, F.T. Hiebert, and R.H. Meadow. 1994. Agriculture and herding in the early oasis settlements of the Oxus civilizations. Antiquity 68(259): 418-427.

Motuzaite Matuzeviciute, G., E. Lightfoot, T.C. O'Connell, D. Voyakin, X. Liu, V. Loman, S. Svyatko, E. Usmanova, and M.K. Jones. 2015. The extent of cereal cultivation among the Bronze Age to Turkic period societies of Kazakhstan determined using stable isotope analysis of bone collagen. Journal of Archaeological Science 59: 23-34.

Morgan, E.D. and C.H. Coote. 1886. Early voyages and travels to Russia and Persia by Anthony Jenkinson and other Englishmen. London: Hakluyt Society.

Mukhamdejanov, A.R. 1994. Economy and social system in Central Asia in the Kushan Age. In J.Harmatta, B.N.Puri, and G.F.Etemadi (eds.) The history of civilizations of Central Asia, vol. II: the development of sedentary and nomadic cultures. Paris: UNESCO. Pp265-290.

Negus Cleary, M. 2015. Kalas and kurgans: some considerations on late Iron Age pastoralism within the Central Asian oasis of Chorasmia. In P.N. Kardulias (ed.) The ecology of pastoralism. Boulder: University of Colorado Press. Pp117-170.

Negus Cleary, M. 2013. Khorezmian walled sites of the seventh century BC - fourth century AD: Urban settlements? Elite strongholds? Mobile centres? Iran 51: 71-100.

Negus Cleary, M. 2008. Walls in the desert: the phenomenon of Central Asian urbanism in ancient Khorezm. In K.Parry (ed.) Art, architecture, and religion on the Silk Roads. Brepols: Ancient History Documentary Research Centre, Macquarie University. Pp51-78.

Nerazik, E.E. 1976. Sel'skoe zhilishche v Khorezme (I - XIV vv.). Moscow: Nauka. 
Oberhänsli, H., N. Boroffka, P. Sorrel and S. Krivonogov. 2007. Climate variability during the past 2000 years and past economic and irrigation activities in the Aral Sea Basin. Irrigation and Drainage Systems 21: 167-183.

Oberkircher, L. and A.-K. Hornidge. 2011. "Water is life" - farmer rationales and water saving in Khorezm, Uzbekistan: a lifeworld analysis. Rural Sociology 76(3): 394-421. poster

O'Hara, S.L. 2000. Lessons from the past: water management in Central Asia. Water Policy 2(4-5): 365-384.

O'Hara, S.L. and T. Hannen. 1999. Irrigation and water management in Turkmenistan: past systems, present problems and future scenarios. Europe-Asia Studies 51(1): 21-41.

Olufsen, O. 1911. The Emir of Bokhara and his country. Copenhagen: Gyldendalske Boghandel, Nordisk Forlag.

Ostrom, E. and R. Gardner. 1993. Coping with asymmetries in the commons: self-governing irrigation systems can work. Journal of Economic Perspectives 7(4): 93-112.

Penne-Firme, R. 2013. Political and event ecology: critiques and opportunities for collaboration. Journal of Political Ecology 20: 199-216.

Pravilova, E.A. 2009. River of empire: geopolitics, irrigation, and the Amu-Darya in the late XIXth century. In S.Gorshenina and S.Abashin (eds.) Le Turkestan russe: une colonie comme les autres? Tashkent: IFEAC. Pp254-287.

Reinhardt, C., B. Wünnemann, and S. K. Krivonogov. 2008. Geomorphological evidence for the late Holocene evolution and the Holocene lake level maximum of the Aral Sea. Geomorphology 93: 302315.

Rogers, J.D., E. Ulambayar, and M. Gallon. 2005. Urban centres and the emergence of empires in eastern Inner Asia. Antiquity 79: 801-818.

Saidov, A., A. Anarbaev, and V. Goriyacheva. 2011. The Ferghana valley: the pre-colonial legacy. In S.F.Starr, B.Beshimov, I.I.Bobokulov, and P.Shozimov (eds.) The Ferghana valley: the heart of Central Asia. Armonk, NY: M.E. Sharpe. Pp3-28.

Sala, R. 2012. Medieval urbanization of mid-low Syrdarya and northern Tienshan: structure, development and environmental impact. In Towards a sustainable society in Central Asia: an historical perspective on the future. Kyoto: RIHN. Pp59-74.

Sala, R. 2003. Historical survey of irrigation practices in west Central Asia. Almaty: Laboratory of Geoarchaeology, Institute of Geological Sciences, Ministry of Education and Sciences of Kazakhstan.

Sarianidi, V. 1992. Food-producing and other Neolithic communities in Khorasan and Transoxiana: eastern Iran, Soviet Central Asia, and Afghanistan. In A.H.Dani and V.M.Masson (eds.) History of the Civilizations of Central Asia, vol.1. Paris: UNESCO Publishing. Pp109-126.

Scarborough, V.L. 2003. The flow of power: ancient water systems and landscapes. Santa Fe, NM: School of American Research.

Schiffer, M.B. and J.M. Skibo. 1997. The explanation of artifact variability. American Antiquity 62(1): 27-50.

Shioya, A. 2014. Povorot and the Khanate of Khiva: a new canal and the birth of ethnic conflict in the Khorazm oasis, 1870s -1890s. Central Asian Survey 33(2): 232-245.

Sinopoli, C.M. 1994. Monumentality and mobility in Mughal capitals. Asian Perspectives 33(2): 293-308.

Sneath, D. 2007. The headless state: aristocratic orders, kinship society and misrepresentations of nomadic Inner Asia. New York: Columbia University Press.

Sorrel, P., S.-M. Popescu, M. J. Head, J. P. Suc, S. Klotz and H. Oberhänsli. 2006. Hydrographic development of the Aral Sea during the last 2000 years based on a quantitative analysis of dinoflagellate cysts. Palaeogeography, Palaeoclimatology, Palaeoecology 234: 304-327.

Sorrel, P., S.-M. Popescu, S. Klotz, J.-P. Suc, and H. Oberhänsli. 2007. Climate variability in the Aral Sea Basin (Central Asia) during the late Holocene based on vegetation changes. Quaternary Research 67: 357-370. 
Spengler, R.N., M.D. Frachetti, and P.N. Domani. 2014. Late Bronze Age agriculture at Tasbas in the Dzhungar Mountains of eastern Kazakhstan. Quaternary International 348: 147-157.

Stride, S. 2007. Regions and territories in southern Central Asia: what the Surkhan Darya province tells us about Bactria. In J.Cribb and G.Herrmann (eds.) After Alexander: Central Asia before Islam. Oxford: Oxford University Press. Pp99-117.

Stride, S., B. Rondelli, and S. Mantellini. 2009. Canals versus horses: political power in the oasis of Samarkand. World Archaeology 41(1): 73-87.

Swyngedouw, E. 1999. Modernity and hybridity: nature, regeneracionismo, and the production of the Spanish waterscape, 1890-1930. Annals of the Association of American Geographers 89(3): 443-465.

Swyngedouw, E. 2009. The political economy and political ecology of the hydro-social cycle. Journal of Contemporary Water Research and Education 142(1): 56-60.

Swyngedouw, E. 2015. Liquid power: contested hydro-modernities in twentieth century Spain. Cambridge, MA: MIT Press.

Teichmann, C. 2007. Canals, cotton, and the limits of de-colonization in Soviet Uzbekistan, 1924-1941. Central Asian Survey 26(4): 499-519.

Thompstone, S. Russian imperialism and the commercialization of the Central Asian cotton trade. Textile History 26(2): 233-257.

Tolstov, S.P. 1948. Drevnii Khorezm. Moscow: Nauka.

Tolstov, S.P. 1962. Po drevnim del'tam Oksa i Iaksarta. Moscow: Izdatel'stvo Vostochnoy Literaturii.

Tolstov, S.P. and A.S. Kes. 1960. Nizov'ia Amu-Dar'i, Sarykamysh, Uzboi, istoriia formirovaniia i zaseleniia. Moscow: Izdatel'stvo Akademii Nauka USSR.

Trevisani, T. 2007. After the kolkhoz: rural elites in competition. Central Asian Survey 26(1): 85-104.

Trevisani, T. 2010. Land and power in Khorezm: farmers, communities, and the state in Uzbekistan's decollectivization. Zurich: Lit Verlag.

Tsalkin, V.I. 1952. Fauna antichnogo i rannesrednevekovogo Khorezma. In Arkheologicheskie i etnograficheskie raboty Khorezmskoi ekspeditsii 1945-1948. Moscow: Izdatel'stvo Akademii Nauk USSR. Pp213-246.

Tsalkin, V.I. 1966. Drevnee zhivotnovodstvo plemen Vostochnoi Evropy i Srednei Azii. Moscow: Nauka.

Tsvetsinskaya, E.A., B.I. Vainberg, and E.V. Glushko. 2002. An integrated assessment of landscape evolution, long-term climate variability, and land use in the Amudarya Prisarykamysh Delta. Journal of Arid Environments 51: 363-381.

United Nations Development Programme - Uzbekistan (UNDP-Uz). 2011. Sustaining livelihoods affected by the Aral Sea disaster. United Nations Development Programme Report, 61 pps.

United Nations Environment Programme (UNEP). 2005. Global international waters assessment: Aral Sea. Kalmar, Sweden: University of Kalmar.

Vainberg, B.I. 1979. Pamyatniki Kuyusayskoy kul'turi. In Itina, M.A. (ed.) Trudy Khorezmskoi arkheologoetnograficheskoi ekspeditsii XI: kochevniki na granitsakh Khorezma. Moscow: Nauka. Pp1-76.

Vayda, A. 1983. Progresssive contextualization: methods for research in human ecology. Human Ecology 11: 265-281.

Vayda, A. 1990. Actions, variations, and change: the emerging anti-essentialist view in anthropology. Canberra Anthropology 13(2): 29-45.

Vayda, A. 1994. Actions, variations, and change: the emerging anti-essentialist view in anthropology. In R.Borofsky (ed.) Assessing cultural anthropology. New York: McGraw-Hill. Pp320-330.

Vayda, A. and B.J. McCay. 1975. New directions in ecology and ecological anthropology. Annual Review of Anthropology 4: 293-306. 
Vayda, A. and B.J. McCay. 1977. Problems in the identification of environmental problems. In T.P. BaylissSmith and R.G.A. Feachem (eds.) Subsistence and survival: rural ecology in the Pacific. London: Academic Press. Pp411-418.

Vayda, A. and B. Walters. 1999. Against political ecology. Human Ecology 27: 167-179.

Veldwisch, G.J. and M. Spoor. 2008. Contesting rural resources: emerging 'forms' of agrarian production in Uzbekistan. Journal of Peasant Studies 35(3): 424-451.

Walters, B.B., B.J. McCay, P.West and S.Lees. 2008. Against the grain: the Vayda tradition in human ecology and ecological anthropology. Lanham, MD: AltaMira Press. introduction

Walters, B. and A. Vayda. 2009. Event ecology, causal historical analysis and human environment research. Annals of the Association of American Geographers 99(3): 534-553.

Wegerich, K. 2000. Water user associations in Uzbekistan and Kyrgyzstan: study on conditions for sustainable development. School of Oriental and African Studies Water Issues Study Group Occasional Paper 32. London: University of London.

Wegerich, K. 2010. Handing over the sunset: external factors influencing the establishment of water user associations in Uzbekistan: evidence from Khorezm province. Gottingen, Germany: Cuvillier Verlag Gottingen.

Wittfogel, K. 1957. Oriental despotism: a comparative study of total power. New Haven: Yale University Press.

White, K.D. 2013. Nature-society linkages in the Aral Sea region. Journal of Eurasian Studies 4: 18-33.

Yagodin, V.N., A.V.G. Betts, F. Kidd, E. Baker Brite, S. Amirov, V.V. Yagodin, and G. Fray. 2009. Karakalpak-Australian excavations in ancient Chorasmia. an interim report on the Kazakly-yatkan wall paintings: the 'portrait' gallery. Journal of Inner Asian Art and Archaeology 4: 7-42.

Zanca, R. 2000. Kolkhozes into shirkats: a local label for managed pastoralism in Uzbekistan. Washington, D.C.: National Council for Eurasian and East European Research.

Zanca, R. 2011. Life in a Muslim Uzbek village: cotton farming after communism. Belmont, CA: Wadsworth.

Zonn, I.S. 2009. Farming (historical) in the circum-Aral area. In I.S.Zonn, M.Glantz, A.G.Kostianoy, and A.N.Kosarev (eds.) The Aral Sea encyclopedia. Berlin: Springer-Verlag. Pp95-97. 